\title{
Arketipsel İmgelerin İkna Boyutu ve Türk Reklamlarında Görülme Sıklığı Üzerine Bir Araştırma*
}

\author{
Sezgin Savas \\ doktora öğrencisi, istanbul üniversitesi, iletişim fakültesi \\ halkla ilişkiler ve tanıtım bölümü \\ sezgin.savas@hotmail.com
}

Sevimece Karadoğan Doruk profesör doktor, istanbul üniversitesi, iletişim fakültesi halkla ilişkiler ve tanıtım bölümü ecek@istanbul.edu.tr

\begin{abstract}
Research on Persuasion Dimension of The Archetypal Images and Usage Frequency of Archetypes In Turkish Advertisements

The purpose of this article is to show how frequently and for what purpose archetypal images are used in Turkish advertisements and to analyze which archetypes are preferred on sectoral basis. This study consists of three parts. In the first part, the theoretical framework of the concept of persuasion is stated. In the second part, the connection between advertising and the concept of archetype is examined and it is focused on the role of the relevant connection in the process of persuasion. In the third part, through advertising analysis it is revealed whether archetype exists in advertisements and which archetype is used predominantly in which sector. Results of the study reveal that archetypes are used consciously in advertisements for persuasion and specific archetypes are consciously chosen to deliver a message.
\end{abstract}

keywords: advertising, persuasion, archetype, Jung, subconscious

* Bu çalışma aynı başlıkla 2016 yılında İstanbul Üniversitesi'nde sunulmuş yüksek lisans tezinden üretilmiştir. 


\section{Résumé}

\section{Dimension persuasive des images archétypiques et fréquence d'utilisation dans la publicité turque}

Cet article analyse fréquence et des objectifs de l'utilisation des images archétypiques dans la publicité turque par secteurs d'activité. La première partie du travail pose le cadre théorique du concept de persuasion. La deuxième partie étudie le lien entre l'archétype et la publicité pour mettre ensuite l'accent sur le rôle de ce lien dans le processus de persuasion. La troisième partie interroge si les images archétypiques sont utilisées dans la publicité et quelles images sont les plus fréquemment utilisées par quels secteurs d'activité. A l'issue de cette analyse, un tableau général des images archétypiques par secteurs d'activités est dressé, chaque secteur utilisant une image archétypique dominante différente. Des inférences sont faites quant au sens donné à chaque archétype dominant par le secteur d'activité en faisant usage. Les résultats de ces inférences montrent que les images archétypiques sont choisies et utilisées afin d'ancrer le message publicitaire dans les esprits et d'augmenter son pouvoir de persuasion. Par ailleurs, le choix de ces images se fait notamment en fonction de la spécificité de chaque secteur. Cette conclusion donne également des indices quant à la structure de planification et l'objectif final d'une publicité.

mots-clés: publicité, persuasion, archétype, Jung, subconscient

\section{Öz}

Bu makalenin amacı Türk reklamlarında arketipsel imgelerin ne sıklıkla ve hangi amaçla kullanıldığını ortaya koymak, sektörel bazda hangi arketiplere yoğunlaşıldığına yönelik çözümleme sunmaktır. Çalışma üç bölümden oluşmaktadır. Çalışmanın ilk bölümünde ikna kavramının kuramsal çerçevesi ortaya koyulmuş; ikinci bölümde reklamlarla arketip kavramı arasındaki bağlantı irdelenerek, söz konusu bağlantının ikna edebilme aşamasındaki rolüne odaklanılmıştır. Üçüncü bölümde ise reklam analizi yoluyla reklamlarda arketip bulunup bulunmadığı ve hangi sektörde hangi arketipin baskın olarak kullanıldığı ortaya çıkarılmıştır. Bunu takiben sektörel anlamda baskın arketipin değişmesinin anlamına yönelik çıkarımlarda bulunularak genel bir tablo ortaya koyulmuştur. Araştırmanın sonuçları arketiplerin reklamlarda ikna amacı ile bilinçli olarak kullanılı̆̆ını ve sektörlerin yapısına göre yine bilinçli olarak, zihinde mesaj oluşturmak için belirli arketiplerin tercih edildiğini ortaya koymaktadır.

anahtar kelimeler: reklam, ikna, arketip, Jung, bilinçaltı 


\section{Giriş}

Reklam, yüzyıllardan beri kendini çeşitli formlarda göstermiş ve sürekli yenilemiş bir kavramdır. Ortaya çıkışından itibaren reklamların amacı insanları ikna etmek olmuştur. Tüketim toplumunun önemli bir aktörü olarak reklamlar, insanların eğilimleri ve zihin kalıplarıyla bağlantılar kurarak insanlara onların intiyaçlarından bağımsız olarak belli ürünleri satın aldırmaya odaklanmıştır. Bu bağlamda, tutum ve davranışların manipülasyonu önemli bir hâl almıştır. İlerleyen aşamalarda reklamın kullanım alanları genişlemiş, müşterilerle iletişim kurma ve imaj oluşturma aşamalarında da kullanılan bir araç haline gelmiştir.

Reklamlar tarihsel olarak belli niceliksel ve niteliksel dönüşümlere uğramışlardır. Zaman içerisinde reklamlar gündelik yaşamın farklı mecralarında karşımıza çıkan ve kaçınıması mümkün olmayan iletiler halini almıştır. Bu niceliksel artış, markaları önemli bir sorunla karşı karşıya getirmiştir. Tüketicilerin yüzlerce reklam arasında belli bir markayı hatırlaması nasıl mümkün olabilecektir? Bu sorunun çözümünde reklamların içeriğine yönelik, yani niteliksel dönüşümler ön plana çıkmıştır. İçerik bağlamında, hatırlanabilirliği artıırmak amacıyla yaratıcılık ve hikayeleştirme ön plana çıkmış, geleneksel, ürüne odaklanan reklamlar kaybolmaya yüz tutmuştur. Bugün, reklamın içeriğinin ürünün kalitesi kadar önemli hale geldiği söylenebilir.

İçerik oluşturma aşamasında sembollerin büyük önemi vardır. İnsanlar bilindik sembollerin etkisine daha açık bir yapıdadır. Tanıdığımız, güvendiğimiz ve saygı duyduğumuz insanların sözlerine itibar etmemizin, onların verdikleri öğütleri dinlememizin sebebi söz konusu insanlarla ilgili algılarımızdır. Reklamlar da benzer bir etkiden yararlanmaktadır. Beğenilen bir reklam akılda kalıcı bir nitelikte olabilir, ancak bilindik sembollerle desteklenmiş bir reklam beğeniden daha iyi sonuçlar doğurabilmektedir.

Reklamlarda kullanılan bilindik sembollere en iyi örneklerden biri Carl Jung'un arketip kavramıdır. Arketipsel imgeler, atalarımızın deneyimlerinin, davranışlarının ve rollerinin kendimizde veya diğer insanlardaki kalıntılarıdır ve Jung'a göre bu unsurlar kolektif bilincin bileşenlerindendir. Bu bağlamda, reklamlarda kullanılan bilindik sembollerin önemli bir kısmının, Jung'un tabiriyle arketip olduğunu öne sürmek mümkündür.

Bu kavramsal arka plana dayanarak, bu araştırma Türkiye televizyonlarındaki reklamlarda kullanılan arketiplerin kullanım sıklığı ve çeşitliliğini ortaya koymayı amaçlamaktadır. Araştırma, Türkiye'de en çok reyting alan zaman diliminde gösterilen televizyon reklamlarında arketiplerin kullanılma sıklığına ve sektörel olarak arketip kullanımının dağılımına odaklanmaktadır.

Çalışma üç bölümden oluşmaktadır. Çalışmanın ilk bölümünde iknanın kavramsal çerçevesi ve işleyişi ortaya koyulmakta; etkili bir iknanın nasıl 
gerçekleştiği üzerine yoğunlaşımaktadır. İkinci bölümde, arketip kavramı açıklanmakta ve reklamın arketiplerle bağlantısı irdelenmektedir. Üçüncü bölümde ise çalışmanın öznelliğini oluşturan reklam ve arketip bağlantısına yönelik analizin verileri sunulmaktadır.

Araştırmayı on kodlayıcı gerçekleştirmiştir. Araştırmaya katılan on kodlayıcının cevapları arasında anlamlı derecede tutarlılık bulunmaktadır ve incelenen reklamlarda bulunan arketiplere yönelik sonuçlar önemli bulgular ortaya koymaktadır. Bu bağlamda, hem genel olarak belli arketiplerin Türk reklam sektöründe baskın olduğu, hem de kullanılan arketiplerin sektörel bazda değişkenlik gösterdiği gözlemlenmiştir. Dolayısıyla Türk televizyonlarında gösterilen reklamların bilinçli olarak arketipleri kullandığı sonucuna ulaşıımış; söz konusu arketiplerin ürünün niteliği, yani yer aldığı sektöre göre bilinçli olarak yerleştirildiği ortaya konulmuştur. Ancak arketiplerin kültürel bağlamda farklılık içerebildiği unutulmamalıdır. Dolayısıyla söz konusu çalışma yalnızca Türkiye için bir anlam ifade etmekte, tüm dünyadaki reklamların genellenmesine bir temel oluşturmamaktadır.

\section{íknaya Yönelik Kuramsal Çerçeve}

Kapitalist düzene entegre olmayla eş zamanlı olarak insanların intiyacı olan veya olmayan mal ve hizmetleri satabilme aşamasında öne geçme çabaları ortaya çıkmıştır. Kurumlar veya kişiler rekabetin üst düzeyde olduğu bir düzende karlarını olabildiğince arttırabilmek için tüketicileri etkileyebilme amacı gütmektedir. Kendilerini seçilir kılabilmek için de farklı yöntemler denemektedirler. İna kavramı da böyle bir ortamda git gide artan bir ilgi ile karşılaşmış ve bu ilgi, ikna edebilmeye yönelik bilimsel bir bakış oluşmasını sağlamıştır.

İkna "bir kanaati kabul ettirme, bir kanaat uyandırma, inanmasını sağlama, razı etme" (Anık, 2000, s. 31) şeklinde tanımlanmaktadır. Ikna herhangi bir zorlama veya baskı gerçekleştirmeden bir başkasının eylem, tutum veya yargılarını konuşma veya diğer iletişim kanallarıyla etkilemek, değiştirmek ve güçlendirmek üzere yapılan faaliyetler bütünüdür (Okur vd., 2013, s. 171). Literatürde kesişme noktaları bulunan tanımlar dahilinde, etik kaygılar ve iletişim olgusu öncelikli tutulduğunda ise genel anlamıyla ikna; bir insana veya topluluğa, bir düşünceyi zorlama olmaksızın, müzakere ve iletişim yollarını kullanarak kabul ettirme, inandırma olarak tanımlanabilir. Diğer bir ifadeyle ikna; istenen davranışın ortaya çıkması için iletişim yoluyla alıııya gerçeğe dayalı ileti ve bilgiler sunarak alıcının istenilen davranışa yönelmesi için ona bilgi sağlamaktır.

İknadan bahsedildiğinde akla şüphesiz manipülasyon olgusu gelmektedir. Farklı disiplinler için ikna, her ne olursa olsun hedefi ikna etmek olarak anlaşılabilmektedir. Bu doğrultuda da etik dışı yöntemler bile meşru görülebilmektedir. Ancak iletişim perspektifiyle ikna, içerisinde daha çok anlam barındırmaktadır. Söz konusu bağlamda ikna sürecinde manipülasyonun 
olabildiğince azaltılarak bireyin rızasının öne çıkarılması gerekliliği önemli bir nokta olarak karşımıza çıkmaktadır. Dolayısıyla, insanların belirli konular hakkında bilgi edinme yoluyla zorlama olmadan tutum veya davranış değiştirebilecekleri noktasından hareketle iletişimin süreçteki değeri kavranabilir. İkna edilmek istenen davranış veya tutum halihazırda etik, diğer bir ifadeyle alıcının zararı ile sonuçlanmayacak bir şey ise müzakere uzlaşma yaratabilecek yegane etkinliklerden biri olarak değerlendirilebilir.

Her iletişimin bir niyet içerdiğinden hareketle, iletişim faaliyetlerinin "bilinçli veya planlı bir şekilde bireyleri etkileme" (Demirtaş Madran, 2012, s. 15) kaygısı içerdiğini, bu doğrultuda da her iletişimin ikna ile iç içe geçtiği söylenebilir. Ancak, iletişimin belirli bir konu çerçevesinde karşılıklı veya tek yönlü bilgi akışını simgelerken, iknanın ise iletişim faaliyeti sırasında alıcının düşüncelerini değiştirmeye yönelik olduğu unutulmamalıdır.

İkna süreci kaynak, mesaj, araç, alııı ve hedef değişkenlerinden oluşmaktadır. “iletişimi başlatan ve gönderilen iletilerin (duygu, düşünce, niyet, fiil vb. içerik) kaynağını temsil eden bir öğe olan kaynak birey, grup, kurum ya da örgüt" (Anık, 2000 , s. 42) olarak karşımıza çıkabilmektedir. "Kaynak, iletinin çıkış ve varoluş sürecine başlatıcı kimliğiyle katııı," (Karadoğan Doruk, 2015, s. 8) dolayısıyla kaynak olmaksızın ikna sürecinden bahsetmek mümkün değildir. Alıcı tarafından iletişim kaynağı doğru ve geçerli sayılırsa, kaynak değerlendirilmeye değer görürse kaynak güvenilirliğe sahip olarak düşünülebilir (Wilson ve Sherrel, 1993, s. 102). İkna sürecinin ikinci değişkeni mesaj, kaynağın hedef kitleye yaptığı aktarım olarak değerlendirilebilir. Mesaj kurgulanırken alıcıya uygun mesaj oluşturulması önemlidir. Mesajın mantıksal, tutarlı ve ilgi çekici olması ikna sürecinin başarısı için önemli görülebilir. Üçüncü değişken araç, iletinin aktarımından sorumlu olan öğedir. Araç, iletinin güvenliğini ve anlamını sağlayan başlıca öğelerdendir. Diğer bir ifadeyle araç mesajdır, yani mesajı iletmek için kullanılan araç mesajın anlamını belirler (Mcluhan, 2001). Bu yüzden de kilit öneme sahip olarak değerlendirilir. Alıcı değişkeni mesajın iletildiği kişi olarak betimlenmektedir. İkna sürecinde alıcıyı tanımak önemli bir unsurdur. "Kişisel ilgililik düzeyi düşük olan iletişimlerde alıcıların bilgiyi işleme ve iknaya direnme motivasyonu minimal düzeyde" (Swasy ve Munch, 1985, s. 878) iken iletinin kişiye yönelik alakalılık düzeyi arttıkça, kişinin hem iletide içerilen bilgiyi işleme hem de o bilgiyi sorgulama düzeyi artmaktadır. Dolayısıyla ikna aşamasında alıcı ile mesajın niteliğinin uyumu, diğer bir ifadeyle alıcıya uygun mesajın oluşturulması önemlidir. Hedef ise sonuç veya etki olarak tanımlanabilmektedir. İknada hedef, tutum ve davranış değişikliği veya devamını sağlamaktır. Dolayısıyla amacın gerçekleşip gerçekleşmediği gözlemle sınanabilir.

İletişimin ikna ile aynı olmadığı, reklamın da bir iletişim biçimi olduğu, "malların, hizmetlerin veya insan faaliyetlerinin herhangi bir yönü ile ilgili mesajların veya enformasyonun sağlanması işleminin" (Seçim, 2013, s. 47) ikna amacı olmadan, sadece iletişimi kullanarak oluşturulabileceği öne sürülebilir. Ancak, reklam içerisinde 'niyet' barındırır ve iletişime sirayet etmiş bir 'niyet' 
her durumda iknaya vurgu yapmaktadır. Kurumlar, bir ürünü farklı birçok aktörün ürettiği ve rekabetin genişlediği serbest piyasa düzeninde marka tercihi oluşturma, müşterileri markalarını değiştirmeye teşvik etme, algılar üzerinde oynama (Solmaz, 2014, s. 53) gibi olguları yalnızca iletişim kurarak sağlamayacaklarının farkında olarak değerlendirilebilirler. Bu durum reklamcılığa olan ilginin artması ve ikna edici mesaj (bilinçdışı mesajlar dâhil) stratejilerinin gelişmesi için bir etken olarak düşünülebilir.

Reklamın "silahı bizim güçsüzlüklerimizdir: korku, tutku, hastalık, gurur, bencillik, istek, cehalet. Ve bu silahlar bir kılıç kadar keskindir" (Tosyalı, 2014, s. 37). İlgili silahlar reklam ve ikna ilişkisi bağlamında düşünülebilecek bileşenlerdir. Insan bir konuda kendi hakkında bir yoksunluk hissediyorsa, yoksunluğunu giderebileceği vaadi ikna açısından avantaj sağlamaktadır. "Reklam metinlerinde, yaşam tarzı sunumuna yönelik reklamların ağırlıkta olması" (ileri, 2012, s. 36) tam da bu yüzdendir. Reklam karakterlerinin sunduğu yaşam tarzlarına öykünen izleyiciler kendi yaşamlarının da benzer bir niteliğe ulaşması umuduyla ikna olabilmektedir. Pazarlama özelinde reklam faaliyetlerinin yaşam tarzı reklamlarına yönelmelerinin altında bu sebep aranabilir.

Kısaca, televizyonun sahip olduğu güç ve erişim yeteneğine yaslanan reklamın, yapısı itibariyle ikna ile iç içe geçmiş bir kavram olduğu söylenebilir. İki olgunun tam olarak birbiri ile iç içe olduğu söylenemese de birbirlerinden kesin çizgilerle ayrıldıklarını iddia etmek de olanaksız olarak değerlendirilebilir.

Tüm bu bağlamda düşünüldügünde, iknanın planlı ve belirli adımlar izlenerek yapılan bilinçli bir çaba olduğunu söylenebilir. İnsan psikolojisine dayanan temellerinin yanında ikna çabaları, iletişimi de içinde barındırarak kendini gerçekleştirme adına farklı mecraları da kullanmaktadır. Bu noktada da teknolojik imkânların arttığı günümüzde, özellikle kitle iletişim araçlarında kendine fazlaca yer bulan reklamın, iknayı kolaylaştırdığı varsayılan öğeleri ne oranda içerdiği önemli bir konu olarak karşımıza çıkmaktadır. İknayı kolaylaştırmaya yönelik içerik dendiğinde de akla şüphesiz arketip kavramı gelmektedir.

\section{Arketipler ve Arketiplerin Reklamlarda Kullanımı}

Arketiplerin ne olduğu ve reklamlarda nasıl kullanıldığını ortaya koyabilmek için öncelikle Jung'un düşünsel pratiğine ve arketipe yüklediği anlamlara odaklanmak gerekmektedir. Jung, psikoloji bilimine önemli katkılarda bulunmuş ve kendisinden önce üzerine düşünülmemiş kavramlara odaklanmıştır. Bu bağlamda Jung'un literatüre en büyük katkılarından birinin, kolektif bilinçdışı kavramına odaklanarak arketipleri ortaya koymasından kaynaklandığı söylenebilir. Kolektif bilinçdışı, insanın bilincinde yaşanmamış olan ve geçmiş yaşantılardan kendisine kadar ulaşmış bir deneyimler bütünü olarak tanımlanabilmektedir. Kalıımsal nitelik taşıyan bu olgu insanın doğumundan itibaren içinde taşıdığı gizli 
bir bellek olarak algılanabilmektedir. Jung, sunduğu arketip konsepti ile insan davranışlarının temellerine yönelik çözümleme sunmaktadır.

"Arketipler kolektif bilinçaltının içerikleri olarak bilinirler" (Jung, 1969, s. 4). Jung'a göre arketipsel imgeler ilk imgelerdir ve söz konusu imgelerin ortaya çıkışı insan türünün varoluşuyla aynı zamana denk gelir. Bu imgeler insanı insan kıldığı için insan eylemlerinin insana özgü biçimidir. Arketipler her insanın zihninde vardır ve bunu reddetmek, yani bu tarz imgelerin her insanda yeniden bir deneyimle süreciyle üretildiği her gün doğan güneşin farklı bir güneş olduğunu iddia eden ilkel inanç kadar gerçek dışıdır (Jung, 2013, s. 20). Bu bağlamda Jung'un ilksel imge bizim ise konumuz kapsamında arketipsel imge olarak bahsettiğimiz imgelerin atalarımızın deneyimlerinin, davranışlarının, rollerinin kendimizde veya diğer insanlarda vücut bulmuş hali olduğu söylenebilir. "İmge insan yapısıdır. İmgeler, orada bulunmayan şeyleri gözde canlandırmaya" (Berger, 2011, s. 9) yarar. Kısaca, geçmiş insan yaşantılarının, insan yapısının yeniden yaratılmış halidir. Bu doğrultuda da arketipler, yaşamda karşılaştığımız bazı durumların etkisiyle atalarımızın deneyimlerinin veya biçimlerin imgeleme (zihnimizde canlandırma) yoluyla zihnimizde belirmesi, bilinç düzeyine ulaşması olarak tanımlanabilir.

Arketipler bir olayı ve olguyu deneyimlemeye yönelik içsel bir eğilim olduğundan davranışlarımızın üzerinde düzenleyici bir işlev üstlenirler. Örneğin, belirli korkularımız veya isteklerimiz zihnimizde halihazırda kodlanmış bulunmaktadır. Bu kodlar canlı görüntüler olmasa, yani kişisel deneyime dayanmasa da bizimle birliktedirler. Söz konusu korkuların veya isteklerin kökenini bilmeyiz, fakat yine de karşı koyamayız. Fare, yılan ve böcekten korkmak, tüm yiyecekler arasından belirli yiyecekleri beğenmek bunun iyi bir temsilidir. Kişiliğin oluşumunu derinden etkileyen, insan yaşamını şekillendiren, bazı davranışlarımıza kaynaklık eden arketiplerin en başta gelenleri, yani psişeyi düzenleyen arketipler ise; ego, özben, gölge, persona ve anima ve animus olarak sıralanmaktadır.

Ego, insanın bilinç düzeyidir. Ego, özben'in bilinci olan parçasını temsil eder. Düşünce, duygu, algı ve sezgi işlevlerini üstlenir. Egonun baskınlığı kişiliği kendine odaklı bir hale yönlendirebilir. Bu bağlamda da bencilliği yüceltebilir.

Özben, psişenin (zihnin) temel arketiplerinden biridir. Özben bireyin kendini ve çevresini algılamasını sağlar. "Özben', hem bilinci hem de bilinçdışını kucaklayan dairenin bütünüdür" (Jung'dan aktaran Gümüş, 2009, s. 43). Bu artekip, diğer arketiplerin bilinçdışından bilince çıkışını düzenlediği için düzenleme arketipi olarak tanımlanır. Eğer bir insan kendisini denge içinde hissediyorsa özben görevini başarıyla yerine getiriyor demektir.

Persona kişinin egosunun önüne geçen, kısaca egonun gerçek görünümünü gizleyen, topluma ayak uydurabilmek için takındığı maskedir. Dolayısıyla yalnızca farklı bir gerçekliktir (Jung'dan aktaran Demirkol, 2008, s. 74). 
Gölge, persona tarafından onaylanmayan, gerçekleşmesi reddedilen davranışların saklandığı, zihnin karanlık bölümüdür. Persona ile çatışma içindedir, çünkü davranış seçme bakımından sürekli birbirleriyle çatışmaktadırlar. Ego bu çatışmanın ortasında kaldığı için, gölge zihnin karanlık bölümünü, persona ise aydınlık yönünü temsil eder. Persona çevreye uyum sağlamaya yönelik davranışı yüceltirken, gölge toplum tarafından kabul görmeyecek davranışları egoya dayatır. Jung, insanların gölgelerine bakmaktan hoşlanmadığını, bu yüzden uygar toplumda gölgesini kaybetmiş olan birçok insan olduğunu belirtir (Jung, 1976, s. 23). Anima ve Animus ise karşı cinsin özeliklerini zihnin içinde barındırmaya ilişkindir. Jung'a göre kolektif bilinçaltı erkeğe kadın; kadına ise erkek formunda görünür. Jung'un adlandırmasıyla erkeğin içindeki kadına Anima; kadının içindeki erkeğe ise Animus denmektedir (Jung, 1976, s. 89).

Temel arketiplerin yanında belirli yan arketipler de bulunmaktadır. Yukarıda bahsedilen sınıflandırma, Freud'un id, ego ve süperego sınıflandırması gibi zihnin işleyişine yönelik iken diğer arketipler belirli rollere ilişkindir. Söz konusu arketiplerin (kahraman, kral, asi, anne, baba vb.) direkt olarak yaşam boyu davranış üzerinde tesiri olmasa ve zihnimizin içinde pasif olarak bulunsalar da zamanı geldiğinde veya dış etkilerle tetiklenmeleri mümkündür. Örneğin bir kadın anne olduğu an annelik arketipi aktive olmaktadır. Bu yapı da birer mesaj taşıyıcısı olan reklamların, "günümüzde toplumsal gerçeklikten beslendiği ortamda, birtakım imgelerden yararlanarak insanları etkilemeye" (Darıcı, 2013, s. 34) çalıştığı gerçeği göz önüne alındığında anlamlı bir boyuta ulaşmaktadır.

İmge, zihinde yeniden anlamlandırılma ile anılmaktadır. İmgelemede gönderici ve alıcı şeklinde iki taraf arasında ilişki bulmaktadır. Çevreden algılanmış olan her şey bilinçaltına aktarılıp depolanır ve imgeler de bunların arasındadır. İmgeler bir nevi bilinçaltının aynası olarak düşünülebilir. İnsan bilinçaltına aktarıp depoladığı imgeleri koşullar sağlandığında bilince yansıtır. (Karabulut, 2015, s. 3). Reklamların da bu noktada bilinçaltı mesajlarla bir 'çağırma' işlevi üstlendiği söylenebilir. "Bilinçaltı mesajlarda asıl amaç ise ikna etmektir" (Darıcı, 2013, s. 13). Bilinçli zihin bilinçaltına yönelik bilgilerin yalnızca ufak bir bölümünü asimile edebilmektedir. Zihnin bilinçdışı bölümü, değerlerden bağımsız yapısıyla her şeyi kapsayan ve her şeyi içinde alabilecek kapasitededir. Hatırı sayılır oranda insan bilinçaltı mesajların farkına varabilseydi reklamın etkinliği de kaybolurdu. Bilinçli zihin verileri yorumlamak için akılcı, rasyonel davranır, bunun sonucunda da yorumlamaya gider. Bilinçdışı ise değerlerden bağımsız yapısıyla içerisine mesajla girilebilir bir görünümdedir ve bu mesajlar davranış üzerinde etkiye sahip olabilirler (Olson, 1975, s. 4-5). Dolayısıyla, bilinçli, sorgulayabilen zihinden öteye, yani bilinçaltına yönelik mesaj oluşturmanın ikna için gerçekleştirildiği söylenebilir.

Bilinçaltı mesajların etkisine yönelik olarak literatürde çeşitli destekler mevcuttur. Bu bağlamda Kırdar (2012, s. 223), bilinçaltını etkilemek için mesaj gönderme çabalarının 1900'lerde başladığını söylemektedir. Kırdar, bu düşüncesini 1957'de James Vicary'nin yaptığı bir deney ile desteklemektedir. James Vicary, New Jersey'de bir sinema salonu işletmektedir ve 1957 yazında yaklaşık 45.000 
kişinin katılımı ile bir deney gerçekleştirmiştir. Bu deneyde, izleyicilere film sırasında, saniyenin 3000'de 1'i hızında mısır yiyin ve kola için şeklinde bilinçaltı mesajlar gönderilmiştir. Vicary, bu deneyin yapıldığı dönemde mısır ve kola satışının deneyin yapılmadığı döneme göre artış gösterdiğini belirtmektedir. Ancak Vicary'nin bulguları hiç yayınlanmamıştır ve Karremans vd.'nin (2006) aktardığı üzere bir reklam hilesi olup olmadığına yönelik bir tartışma vardır.

Olson $(1975$, s. 3) ise, reklamlardaki subliminal mesajın etkisine yönelik olarak likör reklamlarını incelemiştir. Olson, ön planda viski şişesi, viski bardağı, viski ve buz bulunan bir likör reklamında buzların içinde saklı bir fotoğraftan bahsetmektedir. Bu fotoğrafta, sahilde gün batımı, sarılan iki figür ve arka planda volkan gibi öğeler bulunmaktadır. Olson, bu gizli öğeleri arketipsel teoriye atıfla açıklayarak öğeleri cinsellik ve benzeri sembollerle bağdaştırmıştır. Olson'a göre sessiz bir kumsal ve âşıklar basmakalıp sembollerdir; volkan ve yanardağ sembolü ise hayatın veya cinsel eylemin başlangıcı olarak sembolize edilebilir. Bir bütün olarak buz küpünün içindeki resme bakıldığında cinsellik imâsı vardır. Buradaki bilinçaltı mesaj, viski alın, romantizme sahip olun şeklinde yorumlanabilir. Reklam, bilinçli göze yalnızca bir viski şişesi ve bardağının görünümüyken bilinçaltı için ise farklı detaylar mevcuttur.

Bilinçaltı mesajların etkisinin güçlü olduğunu savunan yaklaşımların yanında, ilgili mesajların belirli şartlarda etkili olduğunu öne süren yaklaşımlar da mevcuttur. Vicary'nin deneyinin gerçekliği tartışılsa da Karremans vd. (2006)'ye göre Vicary'nin bulgularının bir gerçeklik temeli bulunmaktadır. Bilinçaltı mesajlar yoluyla bir buzlu çay markasının içilme istediğinin artıp artmadığına odaklanan Karremans vd.'nin (2006, s. 792) araştırmasında ilgili subliminal mesajların susamış olan insanları etkilediği görülmüştür. Benzer şekilde Bermeitinger vd.'nin (2009) oyun oynayan insanlar üzerine yaptığı araştırmada yorgun insanların oyunda gösterilen marka logolarındaki markayı daha çok tükettikleri sonucu ortaya çıkmıştır. Bermeitinger vd. (2009), basit fizyolojik intiyaçların ötesine geçmek amacıyla Karremans vd.'nin araştırmasında kullanılan 'susama' intiyacından farklı bir ihtiyaca odaklanmış; bu bağlamda 'konsantrasyon' kavramını ele almış ve yorgun insanların konsantrasyonlarını arttırmak için sahip oldukları motivasyonu intiyaç olarak belirlemiştir. Söz konusu iki araştırma bilinçaltı mesajların etkisi konusunda intiyaç odaklılığın önemini ortaya koymaktadır. Uyaran bir ihtiyaçla bağlantılı olduğunda öznelerin bu uyarandan etkilendiği görülmektedir.

Aylesworth vd. (1999), subliminal reklamların etkisi olmadığını öne süren önceki araştırmaların yerleştirmeler ve izleyicilerin reklamlara cevaben oluşturdukları duygular arasındaki ilişkiyi dikkate almadıklarını öne sürmektedirler. Aylesworth vd.'ne göre bilinçaltı yerleştirmelerin izleyiciler üzerinde belli etkileri vardır fakat bu etkiler hem örtüktür hem de tutumlardan ziyade tutumların oluşturma sürecinde ortaya çıkan duygular üzerindedir. Yerleştirmelerin tutumlar üzerindeki net etkisi anlamlı olmayabilir, fakat altta yatan duygular bu yerleştirmelerden etkilenmiş olabilirler. Bu sebeple Aylesworth vd.'ne göre tutum oluşturma sürecinin altında yatan sürecin doğası ve duyguların incelenmesi önemlidir. 
Negatif duygular reklama veya markaya yönelik tutumlara zarar verirken, pozitif duygular tutumu iyileştirirler.

Dolayısıyla bilinçaltı reklamın etkisine yönelik farklı görüşler olduğu söylenebilir. Ancak bilinçaltı reklamın etkisi sınırsız da koşullu da dolaylı da olsa reklamcıların bilinçaltı öğeleri sıklıkla kullandığı ortadadır. Bu durum göz önüne alındığında ve arketiplerin de bilinçaltında yerleşik olarak duran davranış kalıpları olduğuna dikkat çekildiğinde arketiplerin reklamlarda iknayı mümkün kılmak veya güçlendirmek için kullanıldığı söylenebilir. "Arketipsel sembolik temaların sömürüsünün neredeyse bütün reklamları doldurduğu" (Key, 1993, s. 150) iddiası da düşünüldüğünde reklamlarda arketip kullanımının amacını araştırmaktan çok arketiplerin kullanım oranı daha önemli bir boyuta ulaşmaktadır.

Arketiplerin verimli olduğu düşüncesi ve onların yaygın olarak kullanılmasının sebebi her bir insanın bu tarz bir iletişime olan doğal yatkınlığıdır. Arketipler, insanlara tüm sorular hakkında basit bir cevap verir. Insanları zihinsel çabalarla uğraştırmaz ve bilinçaltı düşünce ile uyum içindedirler (Kaftandjiev, 2016, s. 87). Semboller, bilinçli düşünce ve mantığa üstün gelirler. Muğlak, belirsiz ve saklı duyguları harekete geçirirler. Sembolizm subliminal iletişim tekniğini oluşturur. Sofistike, dikkatlice araştırılmış ve güçlü bir sembolik iletişim ticari manipülasyonun temelidir. Semboller algıyı, duyguları ve davranışı doğrudan etkiler (Key, 1993, s. 152). Dolayısıyla, davranışların bireyin farkındalığı olmaksızın manipüle edilebileceği söylenebilir. Reklamlar da geniş nüfusa ulaşabildiğinden bu noktada önemli bir konuma yükselmektedir. Reklamlarda ne oranda arketip kullanıldığı aslında ilgili reklamların ne denli iknaya dönük olarak hazırlandığının belirli bir kanıtını sunmaktadır. Özellikle sektörel bağlamda düşünüldüğünde hangi sektörlerin iknaya daha fazla ihtiyaç duyduğunun tespiti genel olarak sektöre yönelik bakış açısını ve izleyicinin gözündeki imajı değiştirmeye yönelik çabaların niteliğini de tespit etmektedir.

\section{Araştırma}

\section{Araştırmanın Konusu}

Medyada gerek eğlence gerek bilgileri yapılandırmak için yazarlar, öykülerine yansıtıcı karakterler koyarlar. Bu karakterler, izleyicinin kendisini yansıtacağı veya tanımlayacağı karakterlerdir. Bu yansıtıcı karakterler pozitif veya negatif olabilir. Fakat genellikle arketipsel değerleri yansıtırlar (Key, 1993, s. 88). Bu durumun reklamlar için de benzerlik gösterdiği söylenebilir. Medyanın bir uzantısı olarak reklamlar da daha önce bahsedildiği gibi iknayı mümkün kılmak için arketipsel öğelerden yararlanmaktadır. Arketipsel öğeler içeren reklamların ikna boyutunun niteliği tartışılsa da reklamın temel amacının ikna olması ve reklamcıların söz konusu öğelerden sıklıkla yararlanmasının sebebi, iknayı arttırma girişimi olarak değerlendirilebilir. Bu bağlamda, arketiplerin reklamlarda sıklıkla kullanıldığı olgu- 
su (Key, 1993, s. 150) göz önüne alındığında ve reklamların ürün satma ${ }^{1}$ ve imaj oluşturma ${ }^{2}$ gibi uygulamalarda kullanıldığı araştırmalarla desteklendiğinden, arketiplerin, bu tür bir girişimi desteklemek adına hem ürün hem de imaj reklamlarında kullanıldığı düşünülebilir. Bu araştırmanın konusu ise reklamlarda arketip kullanım amacından öte, arketiplerin Türk reklamlarında kullanım sıklığını ve sektörel bazda değişimlerini değerlendirme üzerine yoğunlaşmaktır.

\section{Araştırmanın Amacı}

Araştırmanın genel amacı, sektörel olarak Türk televizyon reklamları ile arketipler arasındaki bağlantıyı ortaya çıkarmaktır. Bu genel amacı gerçekleştirmek üzere ilk olarak arketiplerin Türk reklamcıları tarafından ne sıkıkla kullanıldığı ortaya çıkarılmış; ikinci olarak arketiplerin ürün ve karakterlerde ne oranda yer aldığına ve aynı reklamda kaç farklı arketipin kullanıldığına bakılmış; üçüncü olarak ise sektörel bazda hangi arketipin daha fazla tercih edildiği, bu tercihin önceden planlanmış bir sürecin sonucu olup olmadığına yoğunlaşılmıştır. Bu yolla, arketip olgusuna farklı, daha önce dikkate alınılmamış bir bakış açısından yaklaşılarak Türkiye açısından bir durum tespiti yapıımıştır

\section{Araştırmanın Hipotezleri}

Araştırmanın amacı doğrultusunda Türk televizyon reklamları ile arketipler arasındaki bağlantıyı ortaya çıkarmak üzere dört hipotez belirlenmiştir. İlk hipotez arketiplerin Türk reklamlarında kullanılma sıklığına ilişkindir. İlgili hipotez Key'in (1993, s. 150), "arketipsel sembolik temaların sömürüsünün neredeyse bütün reklamları doldurduğu" iddiasından hareketle ortaya koyulmuştur. İinci hipotez, reklamlarda arketip kullanımının ortaya çıkarılması durumunda arketiplerin reklama ne şekilde eklendiğine ilişkin bir öngörü sunmaktadır. Üçüncü hipotez, Türk televizyon reklamlarındaki genel arketipsel temaya vurgu yaparken, dördüncü hipotez ise arketiplerin sektörel anlamda farklılaşmasına odaklanmaktadır.

Bu bağlamda, araştırma kapsamında aşağıdaki hipotezler test edilmektedir:

H1: Arketipsel imgeler Türkiye'deki televizyon reklamlarında baskın olarak kullanılmaktadır.

H2: Arketipsel imgelerin Türkiye'deki televizyon reklamlarında kullanımı karakter ve ürün bağlamında benzerlik göstermektedir.

H3: Türkiye'deki televizyon reklamlarında yardımsever arketipi baskın olarak kullanılmaktadır.

H4: Türkiye'de gösterilen hizmet sektörüne ait ürünlerin reklamlarda

1 Güleç (2006), reklamların satın alma davranışı üzerinde etkili olduğunu, Ayanwale vd. (2005) ise, tüketicinin ürün seçiminde reklamların etkili olduğunu, en önemli reklam ortamının ise televizyon olduğunu ortaya koymuştur.

2 Demir vd., (2013) ve Yücel (2017)'nin araştırmaları katılımcıların kurumsal reklamlardan etkilendikleri ve ilgili reklamların imaj üzerinde etkisi olduğunu ortaya koymuştur 
yardımsever arketipi baskın olarak kullanılırken, buna benzer olarak diğer tüm ürün kategorilerinde farklı arketiplerin baskınlığı görülmektedir.

\section{Araştırma Modeli ve Yöntemi}

Bu araştırma nicel paradigma bağlamında yürütülmüştür. Diğer bir ifadeyle, araştırma, reklam ve arketip ilişkisini ortaya koymak amacıyla, reklam izleme ve reklamdaki öğelerin oranını tespit etmeye dayanan nicel bir araştırmadır. “Niceliksel araştırmalarda kim, ne, ne zaman, nerede, neden, ne kadar gibi sorulara cevap aranırken, (Sağlam Arı vd., 2009, s. 119) bu araştırmada da benzer olarak, özellikle 'ne kadar' sorusuna odaklanılmış; hangi reklamlarda ne oranda arketip olduğu ortaya çıkarılmaya çalışılmıştır. Araştırma doğrusal bir biçimde ve objektifliği vurgulayarak (Neuman, 2014, s. 260) sayısal veriler üzerinden hareket etmektedir Araştırmada, belirlenen televizyon kanallarındaki reklamlara yönelik analiz uygulanmıştır. Bu bağlamda reklamların içindeki arketipleri tespit etme konusunda ve bu tespit sonucunda çıkarımlar ortaya koymak üzere yeterlilik elde edilmeye çalışılmıştır.

Araştırmanın ilk aşamasında öncelikle 2015 yılı Kasım ayında dört hafta boyunca reyting takibi yapılmış, daha sonra ise reyting rakamlarına göre belirlenen kanallar bir hafta boyunca takibe alınmıştır. Prime-time'ın ilk reklam kuşağını içeren bu takip sonucunda belirlenen dört televizyon kanalındaki reklamlar izlenerek not edilmiş ve örneklemin belirlenmesi için ilk adım atılmıştır.

Araştırmada, kategorileştirme yardımıyla Jung'ın arketipleri göz önüne alınarak örneklem değerlendirilmiştir. Hangi reklamda hangi arketipin bulunduğu ve arketipin üründe mi yoksa karakterlerde mi olduğu incelenmiştir. Her reklamın söz konusu arketip ile bağlantısı irdelenirken, hangilerinde değerlendirilmeye uygun düştüğü (yani birden fazla arketipin de bir reklamda yer alabileceği) belirlenmiş ve her bir reklam için, barındırdığı arketiplere yönelik detaylı açıklamalar yapılmıştır.

Araştırma on kodlayıcı tarafından gerçekleştirilmiştir. Cronbach Alfa değerinin en düşük 0.70 olması gereğinden hareketle (Gürbüz ve Şahin, 2016, s. 325) bu araştırma kapsamında ilgili değerin 0,789 olarak çıkması güvenilirliğin yeterli düzeyde olduğunu ortaya koymaktadır.

\section{Evren ve Örneklem}

Analize temel oluşturmak üzere total grubu reyting verileri 1-30 Kasım tarihleri arasında art arda 4 hafta boyunca takip edilmiştir. Listede bir kanal ilk 5 içerisinde iki veya daha fazla programla yer alabildiğinden listedeki yer sıraları her bir kanal için bir program şeklinde düzenlenmiştir. Buna göre ilgili kanal reyting listesinden en yüksek sırada hangi program ile yer alıyorsa listede o sırada olduğu varsayılmıştır. Yani örnek olarak bir kanal reyting sıralamasında dokuzuncu sırada yer alırken üzerindeki programlardan birkaçı diğer kanalda yayınlandığı için daha 
üst bir sıraya çıkarak ilk $5^{\prime}$ e girmeye hak kazanmıştır. Bu sayede o gün en çok izlenen beş program değil, en çok izlenen beş kanal tespit edilmiştir. Otuz gün sonunda yalnızca dokuz farklı kanalın reyting sıralamasında ilk beş içinde yer aldığı ortaya çıkarılmıştır.

Tablo 1. Televizyon Kanallarının 1-30 Kasım 2015 Tarihleri Arasında Total Grubu Reyting Ölçümünde ilık Beş Sırada Yer Alma Sayısı

\begin{tabular}{|c|c|c|c|c|c|c|c|c|c|}
\hline & $\begin{array}{l}\geq \\
\times \\
\stackrel{x}{\Psi}\end{array}$ & $\stackrel{\infty}{\gtrless}$ & $\frac{0}{\frac{0}{4}}$ & 学 & $\begin{array}{l}\geq \\
3 \\
\text { 운 } \\
\text { 品 }\end{array}$ & 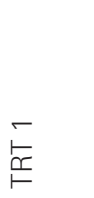 & $\frac{n}{\frac{1}{\zeta}}$ & 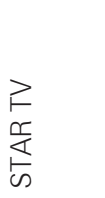 & 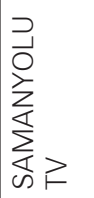 \\
\hline 1. Sırada & 3 defa & 3 defa & 2 defa & 7 defa & 4 defa & 7 defa & 0 defa & 4 defa & 0 defa \\
\hline 2. Sirada & 9 defa & 3 defa & 2 defa & 3 defa & 3 defa & 0 defa & 0 defa & 9 defa & 1 defa \\
\hline 3. Sirada & 14 defa & 3 defa & 2 defa & 4 defa & 5 defa & 0 defa & 0 defa & 1 defa & 1 defa \\
\hline 4. Sırada & 4 defa & 4 defa & 6 defa & 6 defa & 5 defa & 0 defa & 0 defa & 4 defa & 1 defa \\
\hline 5. Sırada & 0 defa & 4 defa & 7 defa & 8 defa & 5 defa & 0 defa & 1 defa & 5 defa & 0 defa \\
\hline Toplam & 30 defa & 17 defa & 19 defa & 28 defa & 22 defa & 7 defa & 1 defa & 23 defa & 3 defa \\
\hline
\end{tabular}

Otuz günlük reyting analizi sonucunda Fox Tv tüm günlerde ilk beşte yer almayı başaran tek televizyon kanalı olmuştur. Fox Tv'yi sırasıyla yirmi sekiz defa ile ATV, yirmi üç defa ile Star TV, yirmi iki defa ile Show TV, on dokuz defa ile Kanal D, on yedi defa ile TV 8, yedi defa ile TRT 1, üç defa ile Samanyolu TV, bir defa ile Kanal 7 takip etmiştir.

Analiz sonucunda en çok birinciliğin yedi defa ile TRT 1 ile ATV arasında paylaşıldığı tespit edilirken, en çok ikinci olan kanallar dokuz kez ile Star Tv ve Fox TV olmuştur. En çok üçüncü olan kanal on dört defa ile Fox TV; en çok dördüncü olan kanallar altı kez ile ATV ve Kanal D; en çok beşinci olan kanal ise sekiz defa ile ATV olmuştur. Bu doğrultuda reyting bazında Fox TV ve ATV'nin baskınlığını görmek mümkündür. Reyting sıralamasında ilk beşte yirmi defadan az yer alan kanallar analiz aşamasında devreden çıkarılacağından, söz konusu analiz kapsamında Fox TV, ATV, Star TV ve Show TV değerlendirilmiştir.

1-30 Kasım 2015 arasındaki dört haftalık incelemeden sonra programların aldıkları reytingler dikkate alınarak öngörüde bulunulup prime-time'da ana haber bülteninden sonraki ilk reklam kuşağı inceleme altına alınmıştır. Dolayısıyla inceleme evrenini ilgili dört kanalın 5-11 Aralık tarihleri arasında cumartesiden cumaya bir hafta süresince haber bülteninden sonraki reklamları oluşturmaktadır.

Söz konusu evren içindeki reklamlar gözlemlendikten ve kayıt altına alındıktan sonra bir hafta boyunca televizyon kanallarında finans, teknoloji, 
gıda, kozmetik ve temizlik, taşımacılık, otomotiv, inşaat, akaryakıt ve enerji, basın, tekstil, mobilya ve diğer olmak üzere toplam 12 kategoride 177 reklamın yayınlandığı tespit edilmiştir. Bunu takiben alternatiften arasından sektörel bazda reklam yoğunluğu değerlendirilmiştir. Sektör kategorileri tüm örneklemdeki reklamlar izlendikten sonra ve reklamların ait olduğu sektörlerin fazlalığına tüm örneklemde en çok hangi sektörlerden reklam varsa o sektörler seçilerek sınırlandırılmaya gidilmiştir- göre finans, teknoloji, gıda, kozmetik ve temizlik, otomotiv, inşaat, akaryakıt ve enerji, mobilya olmak üzere sekiz kategoriye kadar azaltılmıştır.

Incelemeye konu olacak sekiz kategori içinden ise tekrar sıklığı kriterine göre reklamlar belirlenmiştir. Altı defadan az tekrarlanmış reklamlar liste dışı bırakılırken az reklam kapasitesine sahip bazı sektörlerde tekrar sayısı göz ardı edilerek sektöre ait tüm reklamlar incelemeye alınmıştır. Bunun sebebi de sektörler arası reklam anlamında denge sağlamak ve daha tutarlı sonuçlar elde etme şansını arttırmaktır. Söz konusu düşünce ışığında belirlenmiş sektörler ve sektörlere ait reklamlar aşağıdaki gibidir.

Tablo 2. Örneklemdeki Reklamların Sektörel Dağıımı

\begin{tabular}{|c|c|c|c|}
\hline FINANS & TEKNOLOJI & GIDA & KOZMETIK VE TEMIZLIK \\
\hline $\begin{array}{l}\text { - AXA Sigorta } \\
\text { - Anadolu Hayat } \\
\text { - Garanti } \\
\text { - ING Bank } \\
\text { - N N Sigorta } \\
\text { - Vakıfbank } \\
\text { - Yapı Kredi } \\
\text { - enpara.com } \\
\text { - sigortam.net }\end{array}$ & $\begin{array}{l}\text { - Avea Kral Tarife } \\
\text { - Casper Via v9 } \\
\text { - Media Markt } \\
\text { - Turkcell Sesli Kitap } \\
\text { - Turkcell 4.5G } \\
\text { - Turkcell Superonline } \\
\text { - Türk Telekom Telefon } \\
\text { Kütüphanesi } \\
\text { - Vodafone }\end{array}$ & $\begin{array}{l}\text { - Kinder Chocolate } \\
\text { - Domino's Pizza } \\
\text { - Eti Burçak } \\
\text { - Eti Süt Burger } \\
\text { - Eti Karam } \\
\text { - Falım } \\
\text { - Nescafe Mocha } \\
\text { - Ofçay } \\
\text { - Mc Donald's }\end{array}$ & $\begin{array}{l}\text { - Nivea Men Creme } \\
\text { - Nivea Cellular } \\
\text { - Atasun } \\
\text { - CiF Cinderella } \\
\text { - Sofia }\end{array}$ \\
\hline отомотіV & INSSAAT & ENERJI VE AKARYAKIT & MOBILYA \\
\hline $\begin{array}{l}\text { - Bridgestone } \\
\text { - Dacia } \\
\text { - Fiat Egea } \\
\text { - Lassa } \\
\text { - Mitsubishi } \\
\text { - Renault } \\
\text { - Volkswagen } \\
\text { Caddy } \\
\text { - Toyota }\end{array}$ & $\begin{array}{l}\text { - Batışehir } \\
\text { - Deniz İstanbul } \\
\text { - Nidakule Ataşehir } \\
\text { - Nurol Park } \\
\text { - ViaPort } \\
\text { - Venezia }\end{array}$ & $\begin{array}{l}\text { - BP } \\
\text { - Enerji SA } \\
\text { - GO Ipragaz }\end{array}$ & $\begin{array}{l}\text { - Bellona } \\
\text { - İstikbal } \\
\text { - Mondi }\end{array}$ \\
\hline
\end{tabular}

\section{Veriler ve Verilerin Toplanması}

Bu araştırmanın kodlaması iletişim fakültelerinden mezun ve yüksek lisans öğrenimini sürdüren on kişi tarafından yapılmıştır. Reklamlardaki arketiplerin 
ölçümü temel 12 arketip bağlamında gerçekleştirilmiştir. Kodlama kategorileri Margeret Mark ve Carol, S. Pearson'un (2001) The Hero and the Outlaw: Building Extraordinary Brands Through the Power of Archetypes isimli çalışması temel alınarak oluşturulmuştur.

Tablo 3. Arketipler ve Yardım Şekilleri

\begin{tabular}{|l|l|l|l|}
\hline ARKETIP & YARDıM ŞEKLi & ARKETIP & YARDıM ŞEKLi \\
\hline Yaratıcı & Yeni şeyler yaratmak & Kahraman & Cesaretli davranmak \\
\hline Yardımsever & Diğerlerini önemsemek & Asi & Kuralları yıkmak \\
\hline Kral & Hakimiyet kurmak & Büyücü & Dönüşümü etkilemek \\
\hline Soytarı & İyi zaman geçirmek & Masum & İnanç elde etmek \\
\hline Sıradan Adam & Olduğu gibi olmak & Kaşif & Bağımsızığını korumak \\
\hline Aşık & Aşkı bulmak & Bilge & Başkalarını anlamak \\
\hline
\end{tabular}

Kaynak: Mark ve Pearson, 2001, s. 13.

Araştırmaya, kodlayıcıları reklamda mutlaka bir arketip bulmaları yönünde yönlendirmenin önüne geçmek amacıyla hiçbiri seçeneği de eklenmiştir. Kodlama kategorilerinin aranan özellikleri ise aşağıdaki gibidir:

Masum: Masumlara göre hayatta yaşanan olaylar onları kaderlerinde çizilmiş olan yola doğru götürmektedir. Bu teslimiyet sayesinde de temel hedefleri olan mutluluk arayışını gerçekleştirirler (Villate, 2012, s. 3). İyi niyetli, sevgi dolu ve iyimser yapısı onu saflıkla bağdaştırır.

Sıradan Adam: Sıradan adam arketipi toplumla bütünleşmeyi ve bir gruba ait olmayı ister. Gündelik hayata önem verir, pratiktir, toplumun kurallarına ve kendisinden önce oluşturulmuş geleneklere sorgulamaksızın bağııdır. (Siraj ve Kumari, 2011, s. 53). Bu arketip ortalama insanı tanımlar. Ortalama hayallere sahiptir ve toplumdan dışlanma korkusu yaşar.

Kahraman: "Kahraman kendini başarıya teslim eden kişidir" (Campbell, 2008, s. 15). Cesaretli, mücadeleci bir yapıya, ezilene karşı koruma güdüsüne ve saygı arayışına sahiptir.

Yardımsever: Yardımsever, diğerlerine yardım etmeyi amacı haline getirmektedir. Fedakar bir yapıya sahiptir ve dünyayı herkes için daha iyi bir yer haline getirmeye çalışır (McPeek, 2008, s. 54). Yardımsever her şeyi karşılıksız olarak yapar.

Kaşif: Bu karakter genellikle bir çeşit arama görevindedir; bir ev, bilgi, mutluluğun anahtarı veya yalnızca daha iyi bir yol (Taheri ve Jalaly, 2013, s. 248- 
249). Her şeyin daha iyisini bulabileceğini umarak yeni maceralara atılır ve yeni meydan okumalar gerçekleştirir.

Asi: Asi arketipi eylemsellik bağlamında değerlendirilmekte ve yolculuk vurgusuyla birlikte ele alınmaktadır. Ancak bu yolculuk salt bir yolculuktan öte daha iyi olma, istenen kişiye ve yaşayışa ulaşma, bir meydan okuma yolculuğudur (Woodside ve Megehee, 2009, s. 89). Kaşif ile benzerlik taşısa da kaşif bireysel seyahat deneyimlerine odaklanırken asi toplumsal yolculuğunda toplumsal kaygılarla hareket eder. Özgürlük vurgusuyla baskılara göğüs gererek isyan etmekten kaçınmaz.

Aşık: Aşık arketipi çevresindeki herkese sevgi doludur. Duygusal argümanlara dayanarak davranışlarını oluşturur, iletişimden yararlanır ve sevgi, güzellik peşinde koşar (Munteanu vd., 2010, s. 2275). Toplumun işleyişinin anahtarı olarak gördüğünden tüm ilişkilerinde sevgi eksenli davranır.

Yaratıcl:Yaratıcı arketipi insanlara ilham verme ve hayal gücünün potansiyeli ile anılır (Woodside vd., 2012, s. 595). Hayatı anlamlandırmak için bir şeyler yaratır ve hayal etmenin başarının başlangıcı olduğuna inanır.

Soytarı: Soytarı, hayattan zevk almayı amaç edinmiştir. Hedefe odaklı olmak yerine hedefe ulaşma sürecine önem vermektedir (Du Toit ve Coetzee, 2012, s. 5). Soytarı çevresine neşe saçtığı oranda mutluluğa ulaşmaktadır.

Bilge: Aklı ve hayat üzerine sahip olduğu deneyimler yoluyla intiyaç duyanları yönlendirir. Kahraman arketipi ile yakın ilişki içindedir. "Akıl hocası, kahramanın şekillenmesinde ve dönüşümünde çok önemli bir rol oynamaktadır" (Adi vd., 2015, s. 752). Kahramanın kontrolsüz gücünü belirli bir hedefe yönlendirmekte, amacına nasıl ulaşacağı konusunda ona rehberlik etmektedir.

Büyücü: Sihirbaz arketipi masum arketipinden farklı olarak güç konusunda daha talepkardır. Masumlar Tanrı'ya ve evrenin genel akışına güven duyarlar; Sihirbazlar ise hayatı istenen sonuç çerçevesinde sürekli olarak dönüştürüp tevafuka (eş zamanlıı̆̆a/anlamlı tesadüflere) güvenirler (Villate, 2012, s. 3-4).

Kral: Kral arketipi ahlaki kaygılar içeren bir bakış açısıyla gücünü yönetmeye çalışır (Kociatkiewicz ve Kostera, 2012, s. 865). Kral, aklı, cömertliği ve saygınlığıyla diğerinin güvenine sahiptir ve bu yolla diğerlerine de büyüklük kazandııır (Zambo, 2007, s. 126). Yardıma muhtaç olanları korur ve kollar, topluluk içindeki lider olarak kendini öne çıkartır.

Kodlayıcılar ilgili özellikleri kullanarak kodlama gerçekleştirmiş ve arketiplerin üründe mi karakterde mi yoksa her ikisinde birden mi olduğunu tespit etmeye çalışmışlardır. Araştırmanın objektifliğini sağlamak adına kodlayıcılar reklamları tek başına izlemişlerdir. Buna ek olarak, işaretleme baskııını aşmak adına her 
kodlayıcıya reklamlar yalnızca bir kez izlettirilmiştir. Bu şekilde, kodlayıcıların üzerinde baskı oluşturma, yönlendirme yapma veya kodlayıcıların birbiriyle konuşarak birbirinden etkilenmesi yoluyla manipülasyonun oluşması ihtimali ortadan kaldırılmıştır.

\section{Araştırma Bulguları}

Araştırma bulguları, arketip ve reklam ilişkisine yönelik önemli veriler sunmaktadır. Bulgular, reklamlarda arketip bulunup bulunmaması, reklamdaki arketipin üründe mi karakterde mi bulunduğu, hangi sektörde hangi arketipin baskın olarak kullanıldığı, kodlayıcılardan kaç tanesinin aynı reklamda aynı arketipi bulduğu, en fazla arketip bulunan ve bulunmayan reklamın hangisi olduğu, karakterde ve üründe en fazla arketipin tespit edildiği reklamların hangileri olduğu, kodlayıcıların kaç kez reklamlarda arketip bulamadığına yönelik genel bir tablo sunmaktadır. Araştırma bulguları kısaca şu şekilde sınıflandırılabilir:

- Çalışma kapsamında genel anlamda neredeyse tüm reklamlarda arketiplere rastlanılmıştır.

- Hiçbir kodlayıcı altı reklamda karakterde arketip bulamamışken aynı şekilde yine hiçbir kodlayıcı iki reklamda üründe arketip bulamamıştır. Genel bağlamda ise kodlayıcılar toplam 388 kere karakterde arketip bulurken; 363 kere üründe arketip bulmuşlardır.

- Kodlayıcılar, izledikleri reklamlarda, 65 kere hiçbir arketipin bulunmadığı yönünde görüş belirtmişlerdir.

- Toplam 44 reklamda hem üründe hem de karakterde arketip olduğu saptanmıştır. Reklamlarda tespit edilmiş arketiplerin karaktere veya ürüne yönelik olması bakımından sayısal anlamda denge içermesi önemli bir veri olarak karşımıza çıkmaktadır.

- Bazı durumlarda işaretlemeler farklılık gösterse de neredeyse tüm reklamlarda kodlayıcıların 7/10, 8/10, 6/10 gibi oranlarda ilgili reklamda aynı arketipleri saptadıkları söylenebilir.

- Aynı reklamda aynı arketipin hem üründe hem de karakterde mevcut olduğu reklam sayısı 29'dur. Bu bağlamda reklamların sıklıkla baskın arketip temasını hem ürüne hem de karaktere yerleştirerek izleyicideki özdeşleşme oranını arttıramaya çalıştıkları iddia edilebilir.

- Çalışma kapsamında en çok arketip bulunan reklam EnerjiSA reklamı olmuştur. İlgili reklamda 10 kodlayıcı toplam 32 kere arketip bulmuştur. Aşık arketipi 10 kodlayıcının 9'u tarafından bulunurken diğer pek çok arketipte kodlayıcıların 5/10'u hemfikir olmuştur.

- Ayrıca aynı reklam 24 defayla karakterde en fazla arketip bulunan reklam olurken Superonline reklamı 16 defayla en fazla ürüne yönelik arketip saptanan reklam olmuştur. İstikbal reklamı ise 10 kodlayıcının hiçbir arketip bulunmadığına hemfikir olduğu tek reklam olarak dikkat çekici olmuştur. 
- Çalışma kapsamında, en fazla kullanılan arketip 18 kez karakterde 113 kez ise üründe olmak üzere 131 kez bulunan yardımsever arketipi olmuştur.

- En az kullanılan arketip 11 kez karakterde 18 kez ise üründe bulunduğu saptanan kral arketipi olmuştur. Bu bağlamda Türk televizyonlarında gösterilen reklamlardaki markaların kendilerini en çok yardımsevermiş gibi aktardıkları, yani tüketicinin gözünde sempatik, iyiliksever olarak konumlanmaya çalıştıkları söylenebilir.

- Kral arketipinin kullanım azlığını ise yine kültürel nedenlere bağlayabiliriz. Kral arketipinin temel özelliği hükmetmek olduğundan, bu arketipin izleyiciye sempatik gelmemesi korkusu yüzünden kullanılmadığı düşünülebilir. Bu durum Schwartz'ın gerçekleştirdiği ve Türkiye'nin de dahil olduğu, sonuç olarak Türkiye'de 'hükmetmeye' yönelik kültürel eğilimin zayıf olarak bulunduğu çalışma ile de paralellik göstermektedir (Aktaran Batır ve Gürbüz, 2016, s. 428).

Verileri sektör bağlamında değerlendirdiğimizde ise bazı sektörlerde belirli arketiplerde yoğunluk olduğu gözlemlenmektedir.

Tablo 4. Finans Sektörüne Ait Veriler

\begin{tabular}{|c|c|c|c|c|c|c|c|c|c|}
\hline & $\begin{array}{l}\text { Axa } \\
\text { Sigorta }\end{array}$ & $\begin{array}{l}\text { Anadolu } \\
\text { Hayat }\end{array}$ & Garanti & $\begin{array}{l}\text { ING } \\
\text { Bank }\end{array}$ & $\begin{array}{l}\text { N N } \\
\text { Sigorta }\end{array}$ & Vakıfbank & $\begin{array}{l}\text { Yapı } \\
\text { Kredi }\end{array}$ & $\begin{array}{l}\text { enpara } \\
\text {.com }\end{array}$ & $\begin{array}{l}\text { Sigotam } \\
\text { net }\end{array}$ \\
\hline Masum & & 2 Karakter & 3 Karakter & & 3 Karakter & & & & \\
\hline $\begin{array}{l}\text { Siradan } \\
\text { Adam }\end{array}$ & 8 Karakter & & 7 Karakter & & 5 Karakter & 3 Karakter & 7 Karakter & 4 Karakter & \\
\hline Kahraman & $\begin{array}{l}1 \text { Karakter } \\
1 \text { Ürün }\end{array}$ & & & & 1 Ürün & 3 Ürün & & & \\
\hline $\begin{array}{l}\text { Yardımse- } \\
\text { ver }\end{array}$ & 1 Ürün & & $\begin{array}{l}1 \text { Karakter } \\
7 \text { Ürün }\end{array}$ & 1 Ürün & 8 Ürün & 8 Ürün & 4 Ürün & 5 Ürün & 8 Ürün \\
\hline Kaşif & & 7 Karakter & & $\begin{array}{l}1 \text { Karakter } \\
1 \text { Ürün }\end{array}$ & & 1 Karakter & & & 1 Karakter \\
\hline Asi & 2 Karakter & 3 Karakter & & $\begin{array}{l}1 \text { Karakter } \\
1 \text { Ürün }\end{array}$ & & & & & \\
\hline Aşık & & & & & & 1 Ürün & & & \\
\hline Yaratıcı & & & & 3 Ürün & 1 Ürün & 1 Ürün & 2 Ürün & 2 Ürün & \\
\hline Soytarı & & & & 7 Karakter & & & 4 Karakter & 4 Karakter & 1 Ürün \\
\hline Bilge & 1 Karakter & 1 Ürün & 1 Karakter & & 3 Ürün & $\begin{array}{l}1 \text { Karakter } \\
1 \text { Ürün }\end{array}$ & & & \\
\hline Büyücü & & & & & & 1 Ürün & & & \\
\hline Kral & 1 Karakter & & 1 Karakter & & & & & & 3 Karakter \\
\hline Hiçbiri & & & & & & 1 & & & \\
\hline
\end{tabular}

Tabloya Iliş̧kin Verilerin Analizi: Finans sektöründe kodlayıcılar karakterde toplam 81, üründe ise 68 kez arketip bulmuştur. Sektörde en fazla arketip saptanan reklam 21 arketip ile NN Sigorta reklamı olmuştur. Karakterde 13 defayla Axa Sigorta ve Garanti reklamları, üründe ise en fazla arketip saptanan reklam Vakıfbank reklamı olmuştur. Sektörde en fazla kullanılan arketip 1 defa karakterde 
42 defa ise üründe kullanılı̆̆ı saptanan yardımsever olmuştur. Kodlayıcılar tarafından karakterde kullanıldığı en çok saptanan arketip 34 kez ile sıradan adam olurken, üründe en fazla kullanıldığı saptanan arketip yardımsever olmuştur.

Sektör ve Kullanılan Arketiplere Yönelik Analiz: Veriler incelendiğinde; finans sektöründe faaliyet gösteren kuruluşların kendilerini bir yardımsevermiş gibi konumlandırdıkları, diğer bir ifadeyle amaçlarının insanlara yardım etmek olduğunu vurgulamaya çalıştıkları söylenebilir. Yardımsever arketipinin neredeyse tüm kullanımlarının ürüne yönelik olması da bu iddiayı güçlendirmektedir. Direkt olarak ürünle özdeşleştirme yaratılmaktadır. Karakterlerde en fazla kullanılan arketipin sıradan adam olması da; ürünlerin sıradan adamlara, yani hepimize yönelik bir yardım algısı yaratma girişimi olarak düşünülebilir.

Tablo 5. Teknoloji Sektörüne Ait Veriler

\begin{tabular}{|c|c|c|c|c|c|c|c|c|c|}
\hline & Avea & Bimeks & $\begin{array}{l}\text { Casper } \\
\text { Via v9 }\end{array}$ & $\begin{array}{l}\text { Media } \\
\text { Markt }\end{array}$ & $\begin{array}{l}\text { Turkcell } \\
\text { Sesli } \\
\text { Kitap }\end{array}$ & $\begin{array}{l}\text { Turkcell } \\
4.5 \mathrm{G}\end{array}$ & $\begin{array}{l}\text { Turkcell } \\
\text { Superon- } \\
\text { line }\end{array}$ & $\begin{array}{l}\text { Türk } \\
\text { Telekom }\end{array}$ & Vodafone \\
\hline Masum & & & 3 Karakter & & 5 Karakter & 4 Karakter & & 4 Karakter & \\
\hline $\begin{array}{l}\text { Siradan } \\
\text { Adam }\end{array}$ & & & 2 Karakter & & 3 Karakter & 5 Karakter & & 1 Karakter & \\
\hline Kahraman & & & 5 Ürün & 3 Karakter & 2 Karakter & 1 Karakter & 1 Karakter & & \\
\hline $\begin{array}{l}\text { Yardımse- } \\
\text { ver }\end{array}$ & 5 Ürün & 1 Ürün & & & $\begin{array}{l}3 \text { Karakter } \\
9 \text { Ürün }\end{array}$ & 7 Ürün & 2 Ürün & $\begin{array}{l}1 \text { Karakter } \\
8 \text { Ürün }\end{array}$ & $\begin{array}{l}1 \text { Karakter } \\
6 \text { Ürün }\end{array}$ \\
\hline Kaşif & & & & $\begin{array}{l}1 \text { Karakter } \\
1 \text { Ürün }\end{array}$ & & & & $\begin{array}{l}3 \text { Karakter } \\
1 \text { Ürün }\end{array}$ & \\
\hline Asi & & & & 5 Karakter & & & & & \\
\hline Aşık & & & $\begin{array}{l}1 \text { Karakter } \\
1 \text { Ürün }\end{array}$ & 1 Karakter & & & & & \\
\hline Yaratıcı & & 1 Ürün & 1 Ürün & 1 Ürün & 1 Ürün & & $\begin{array}{l}2 \text { Karakter } \\
6 \text { Ürün }\end{array}$ & 2 Ürün & 2 Ürün \\
\hline Soytarı & 4 Ürün & 8 Karakter & & & & & 1 Karakter & 3 Karakter & 9 Karakter \\
\hline Bilge & & 1 Ürün & & 1 Ürün & & 1 Ürün & & 1 Karakter & \\
\hline Büyücü & 1 Ürün & $\begin{array}{l}1 \text { Karakter } \\
1 \text { Ürün }\end{array}$ & 2 Ürün & 1 Ürün & & 1 Ürün & $\begin{array}{l}1 \text { Karakter } \\
8 \text { Ürün }\end{array}$ & 2 Ürün & 1 Ürün \\
\hline Kral & 3 Ürün & & & 1 Ürün & & & & & 2 Karakter \\
\hline Hiçbiri & 1 & & & & & & & & \\
\hline
\end{tabular}

Tabloya Ilişskin Verilerin Analizi: Teknoloji sektöründe; 76 kez karakterde, $88 \mathrm{kez}$ ise üründe arketipe rastladığını görmekteyiz. Sektörde, arketipin en fazla saptandığı reklam 26 kez ile Türk Telekom reklamı olmuştur. Karakterde arketip kullanıldığı en fazla saptanan reklam 13 kez ile Türk Telekom ve Turkcell Sesli Kitap reklamları, üründe ise 13 kez ile Türkcell Süperonline olmuştur. Sektörde en fazla kullanılan arketip 5 kez karakterde, 38 kez ise üründe saptanan yardımsever olmuştur. Kodlayıcılar tarafından karakterde kullanıldığı en çok saptanan arketip 21 kez ile soytarı olurken, üründe ise yardımsever olmuştur. 
Sektör ve Kullanılan Arketiplere Yönelik Analiz: Sektörde 8 kodlayıcı tarafından saptanan soytarı, 9 kodlayıcı tarafından saptanan yardımsever, 8 kodlayıcı tarafından saptanan büyücü arketipleri öne çıkmıştır. Dolayısıyla finans sektörüyle benzer olarak teknoloji sektöründeki markaların da aynı amaçla kendilerini bir yardımsevemiş gibi yansıttığı söylenebilir. Karakterlerde en fazla kullanılan arketipin soytarı olması ise gülmece yoluyla markaların insanları eğlendirerek ikna etmeye çalıştığı yönünde algılanabilir.

Tablo 6. Gıda Sektörüne Ait Veriler

\begin{tabular}{|c|c|c|c|c|c|c|c|c|c|}
\hline & $\begin{array}{l}\text { Kinder } \\
\text { Chocolate }\end{array}$ & $\begin{array}{l}\text { Domino's } \\
\text { Pizza }\end{array}$ & $\begin{array}{l}\text { Eti } \\
\text { Burçak }\end{array}$ & $\begin{array}{l}\text { Eti Süt } \\
\text { Burger }\end{array}$ & $\begin{array}{l}\text { Eti } \\
\text { Karam }\end{array}$ & Falım & $\begin{array}{l}\text { Nescafe } \\
\text { Mocha }\end{array}$ & Ofçay & $\begin{array}{l}\text { Mc } \\
\text { Donald's }\end{array}$ \\
\hline Masum & $\begin{array}{l}10 \\
\text { Karakter } \\
1 \text { Ürün }\end{array}$ & & $\begin{array}{l}2 \text { Karakter } \\
1 \text { Ürün }\end{array}$ & 5 Karakter & 1 Karakter & & & & 1 Karakter \\
\hline $\begin{array}{l}\text { Siradan } \\
\text { Adam }\end{array}$ & 1 Karakter & & $\begin{array}{l}6 \text { Karakter } \\
1 \text { Ürün }\end{array}$ & 1 Karakter & & 3 Karakter & & 2 Karakter & 2 Karakter \\
\hline Kahraman & 1 Karakter & & 1 Ürün & 6 Karakter & & 1 Ürün & & & \\
\hline $\begin{array}{l}\text { Yardımse- } \\
\text { ver }\end{array}$ & $\begin{array}{l}2 \text { Karakter } \\
1 \text { Ürün }\end{array}$ & & $\begin{array}{l}2 \text { Karakter } \\
1 \text { Ürün }\end{array}$ & 1 Karakter & & 1 Ürün & & & \\
\hline Kaşif & & & 1 Karakter & & & & 2 Ürün & & \\
\hline$\overline{A s i}$ & & $\begin{array}{l}2 \text { Karakter } \\
1 \text { Ürün }\end{array}$ & & & & & 2 Ürün & & \\
\hline Aşık & & & & & 2 Ürün & & & & \\
\hline Yaratıcı & & 2 Ürün & & 2 Ürün & & 1 Ürün & 5 Ürün & 1 Ürün & 1 Ürün \\
\hline Soytarı & & 6 Karakter & & & & 8 Karakter & $\begin{array}{l}1 \text { Karakter } \\
2 \text { Ürün }\end{array}$ & & 8 Karakter \\
\hline Bilge & 1 Ürün & & 2 Ürün & & 2 Karakter & & & & \\
\hline Вüyücü & 1 Ürün & & & 1 Ürün & 2 Ürün & 3 Ürün & 1 Ürün & 1 Ürün & \\
\hline Kral & & & & & 1 Ürün & & 2 Ürün & $\begin{array}{l}1 \text { Karakter } \\
1 \text { Ürün }\end{array}$ & \\
\hline Hiçbiri & & 2 & & 1 & 5 & & & 6 & \\
\hline
\end{tabular}

Tabloya Ilişkin Verilerin Analizi: Gıda sektörünü incelediğimizde kodlayıcıların 75 kez karakterde, 45 kez ise üründe arketip bulduğu söylenebilir. Sektörde arketipin en fazla saptandığı reklam 18 kez ile Kinder Chocolate reklamı olmuştur. Karakterde arketip kullanıldığı en fazla saptanan reklam 14 kez ile Kinder Chocolate, üründe ise 14 kez ile Nescafe Mocha reklamı olmuştur. Sektörde en fazla kullanılan arketip 23 kez karakterde, 2 kez de üründe saptanmış olan soytarıdır. Karakterde kullanıldığı en çok saptanan arketip 23 kez ile yine soytarı olurken, üründe ise 12 defayla yaratıcı olmuştur.

Sektör ve Kullanılan Arketiplere Yönelik Analiz: Gıda sektörünün genellikle reklamlarda eğlence ve gülmece temalarından yararlandığı söylenebilir. Gıda sektöründeki yoğun rekabetten dolayı markalar kendilerini eğlenceli kılma yoluyla farklılaştırmaya çalışmaktadır. Bu farklılaştırma kapsamında eğlencenin konusu genel olarak soytarı arketipine sahip karakter, bazen masum ve sıradan insanlar, 
bazen de eğlenceli bir kahraman figürü olmuştur. Ürünlerin kendilerini yaratıcı arketipi ile özdeşleştirmesi de markalarının girişimci ve yenilikçi olduklarına vurgu yapma çabası olarak görülebilir. Ayrıca sektör bağlamındaki arketip tespiti (75K-45Ü) üründen çok karakterlere yoğunlaşıldığını göstermektedir.

Tablo 7. Kozmetik ve Temizlik Sektörüne Ait Veriler

\begin{tabular}{|c|c|c|c|c|c|}
\hline & $\begin{array}{l}\text { Nivea } \\
\text { Men Creme }\end{array}$ & $\begin{array}{l}\text { Nivea } \\
\text { Cellular }\end{array}$ & Atasun & $\begin{array}{l}\text { CiF } \\
\text { Cinderella }\end{array}$ & $\begin{array}{l}\text { Sofia } \\
\text { Ediz Hun }\end{array}$ \\
\hline Masum & & & & & 7 Karakter \\
\hline Siradan Adam & 1 Karakter & 1 Karakter & $\begin{array}{l}7 \text { Karakter } \\
1 \text { Ürün }\end{array}$ & & \\
\hline Kahraman & 7 Karakter & 1 Ürün & 1 Ürün & $\begin{array}{l}3 \text { Karakter } \\
3 \text { Ürün }\end{array}$ & 4 Ürün \\
\hline Yardımsever & & 2 Ürün & $\begin{array}{l}2 \text { Karakter } \\
6 \text { Ürün }\end{array}$ & & 1 Ürün \\
\hline Kaşif & & & 1 Karakter & & \\
\hline \multicolumn{6}{|l|}{ Asi } \\
\hline Așı & 4 Karakter & & & & \\
\hline Yaratıcı & & & & & 1 Karakter \\
\hline Soytarı & & & 1 Karakter & & \\
\hline Bilge & & & 1 Ürün & & $\begin{array}{l}4 \text { Karakter } \\
5 \text { Ürün }\end{array}$ \\
\hline Büyücü & 2 Ürün & 9 Ürün & & 10 Ürün & \\
\hline Kral & $\begin{array}{l}2 \text { Karakter } \\
2 \text { Ürün }\end{array}$ & & & & \\
\hline Hiçbiri & & & & & \\
\hline
\end{tabular}

Tabloya ilişkin Verilerin Analizi: Kozmetik ve temizlik sektöründe $41 \mathrm{kez}$ karakterde, 48 kez ise üründe arketipe rastlanılmıştır. Sektörde, arketiplerin en fazla saptandığı reklam 22 defayla Sofia reklamı olmuştur. Karakterde arketiplerin kullandığı en fazla saptanan reklam 14 defayla Nivea Men Creme, üründe ise 13 defayla CiF reklamı olmuştur. Sektörde en fazla kullanılan arketip 21 kez üründe saptanmış olan büyücü arketipidir. Karakterde kullanıldığı en çok saptanan arketip 12 defayla kahraman olurken, üründe ise 21 defayla büyücü olmuştur.

Sektör ve Kullanılan Arketiplere Yönelik Analiz: Bu bilgiler ışığında ürünlerin kendilerini, bir büyücü olarak, yani mümkün olmayan şeyleri mümkün kılan bir yapıda aktardıkları söylenebilir. Reklamların genel temasına baktığımızda ürünlerin mucizeler yarattığı, sıradan insanların hayatlarına benzersiz farkıııkla ve kolaylıklar kattığı görülebilir. Karakterlerde kullanıldığı en çok saptanan arketipin kahraman olması da büyücünün mümkün kıldıkları sayesinde sıradan adamların, yani hepimizin birer kahramana dönüşeceği vurgusuyla açıklanabilir. Kısaca kozmetik ve temizlik sektörünün mucize vaadi algısına yöneldiği söylenebilir. 
Tablo 8. Otomotiv Sektörüne Ait Veriler

\begin{tabular}{|c|c|c|c|c|c|c|c|c|}
\hline & $\begin{array}{l}\text { Bridges- } \\
\text { tone }\end{array}$ & Dacia & Fiat Egea & Lassa & Mitsubishi & Renault & $\begin{array}{l}\text { Volkswagen } \\
\text { Caddy }\end{array}$ & Toyota \\
\hline Masum & & & 1 Karakter & & & & 2 Karakter & $\begin{array}{l}1 \text { Karakter } \\
1 \text { Ürün }\end{array}$ \\
\hline $\begin{array}{l}\text { Siradan } \\
\text { Adam }\end{array}$ & 1 Karakter & & $\begin{array}{l}1 \text { Karakter } \\
1 \text { Ürün }\end{array}$ & & & 2 Karakter & 4 Karakter & \\
\hline $\begin{array}{l}\text { Kahra- } \\
\text { man }\end{array}$ & 2 Ürün & & & & 2 Ürün & 1 Ürün & & \\
\hline $\begin{array}{l}\text { Yardım- } \\
\text { sever }\end{array}$ & $\begin{array}{l}3 \text { Karakter } \\
2 \text { Ürün }\end{array}$ & & & 1 Ürün & & & & 1 Ürün \\
\hline Kaşif & & & 2 Karakter & & 6 Ürün & & 2 Karakter & \\
\hline Asi & & & $\begin{array}{l}4 \text { Karakter } \\
1 \text { Ürün }\end{array}$ & & 7 Ürün & 2 Karakter & & \\
\hline Aşık & & 2 Karakter & & & & 1 Ürün & 3 Karakter & \\
\hline Yaratıcı & 1 Ürün & & 1 Ürün & & & 1 Ürün & 2 Karakter & \\
\hline Soytarı & & 6 Karakter & & & & 4 Karakter & & \\
\hline Bilge & $\begin{array}{l}7 \text { Karakter } \\
3 \text { Ürün }\end{array}$ & & 6 Karakter & & & & & \\
\hline Büyücü & & & 1 Ürün & & & & 1 Ürün & \\
\hline Kral & & & 1 Ürün & 2 Ürün & & & & \\
\hline Hiçbiri & & 2 & & 7 & & 1 & 2 & 5 \\
\hline
\end{tabular}

Tabloya Illişkin Verilerin Analizi: Otomotiv sektöründe 59 kez karakterde, 37 kez ise üründe arketip tespit edildiğini görmekteyiz. Otomotiv sektöründe arketiplerin en fazla saptandığı reklam 19 defayla Bridgeston ve Fiat Egea reklamları olmuştur. Karakterde arketiplerin en fazla kullanıldığının saptandığı reklam 14 defayla Fiat Egea, üründe ise 15 defayla Mitsubishi olmuştur. Sektörde en fazla kullanılan arketip 13 kez karakterde, 3 kez de üründe saptanmış olan bilgedir. Karakterde kullanıldığı en çok saptanan arketip 13 defayla bilge arketipi iken, üründe ise 8 kez ile asi arketipidir.

Sektör ve Kullanılan Arketiplere Yönelik Analiz: İlgili sektörde daha fazla karakterlere yönelik arketipler kullanıldığı söylenebilir. Sektör reklamlarında ürünler (arabalar) bazen maceracı bir kaşif, genellikle ise mevcut vasat düzeni geliştirmeye yönelik davranan asi olarak; karakterler ise kaşif ve asliği cesaretlendirici ögütler veren bir bilge veya hayatın zevkini çıkaran, anı yaşayan bir soytarı olarak karşımıza çıkmaktadır. 
Tablo 9. Inşaat Sektörüne Ait Veriler

\begin{tabular}{|l|l|l|l|l|l|}
\hline & Batışehir & $\begin{array}{l}\text { Deniz } \\
\text { İstanbul }\end{array}$ & $\begin{array}{l}\text { Nidakule } \\
\text { Ataşehir }\end{array}$ & Nurol Park & $\begin{array}{l}\text { ViaPort } \\
\text { Venezia }\end{array}$ \\
\hline Masum & & & & & \\
\hline $\begin{array}{l}\text { Sıradan } \\
\text { Adam }\end{array}$ & & 1 Karakter & & & 2 Karakter \\
\hline Kahraman & & & & 1 Ürün & \\
\hline Yardımsever & 6 Ürün & 2 Ürün & & 2 Ürün & \\
\hline Kaşif & & & & & 1 Karakter \\
\hline Asi & & & & & \\
\hline Aşık & & & & & 4 Karakter \\
\hline Yaratıcı & 5 Ürün & 6 Ürün & & 1 Ürün & 5 Ürün \\
\hline Soytarı & & & & & \\
\hline Bilge & & & 1 Karakter & & \\
\hline Büyücü & 1 Ürün & 1 Ürün & & 2 Ürün & \\
\hline Kral & & 3 Ürün & & & \\
\hline Hiçbiri & 1 & & 7 & 4 & 3 \\
\hline
\end{tabular}

Tabloya ilişkin Verilerin Analizi: İnşaat sektöründe 9 kez karakterde, 38 kez ise üründe arketip tespit edilmiştir. Sektörde arketiplerin en fazla saptandığı reklam 13 defayla Deniz İstanbul ve ViaPort Venezia olmuştur. Karakterlerde arketiplerin en fazla kullanılığının saptandığı reklam 7 defayla ViaPort Venezia, üründe ise 12 kez ile Batı Şehir ve Deniz İstanbul olmuştur. Sektörde en fazla kullanılan arketip 17 kez üründe saptanmış olan yaratıcıdır. Karakterde kullanıldığı en çok saptanan arketip 4 defayla aşık olurken, üründe ise 17 defayla yaratıcı olmuştur.

Sektör ve Kullanılan Arketiplere Yönelik Analiz: Sektör reklamlarında basitlik öne çıkarılarak reklamlarda karakterlere az başvurulmuştur. Ürüne yönelik arketiplerin baskın olarak yaratıcı arketipi olması da ürünlerin bir yaratıCı gibi insanların hayal ettiği şeyleri gerçekleştirmesi vurgusuyla açıklanabilir. Inş̧aat sektörünün temel vaadi olan güzel yaşam yaratma bu vurguyu uyumlu hale getirmektedir. Karakterlerde bulunan aşık arketipi ise genel olarak reklamlarda yaratıcı ürünün sunduğu güzelliklere aşık olan insanlar olarak karşımıza çıkmaktadır. 
Tablo 10. Enerji ve Akaryakıt Sektörüne Ait Veriler

\begin{tabular}{|l|l|l|l|}
\hline & BP Mustafa Sandal & Enerji SA & GO Ipragaz \\
\hline Masum & & 5 Karakter & \\
\hline Sıradan Adam & 2 Karakter & 5 Karakter & 3 Karakter \\
\hline Kahraman & & 2 Karakter & 1 Ürün \\
\hline Yardımsever & & $\begin{array}{l}\text { 2 Karakter } \\
5 \text { Ürün }\end{array}$ & 1 Ürün \\
\hline Kaşif & & & \\
\hline Asi & & & \\
\hline Aşık & & 9 Karakter & \\
\hline Yaratıcı & & & 4 Ürün \\
\hline Soytarı & 1 Karakter & 1 Karakter & \\
\hline Bilge & 3 Karakter & & 3 Ürün \\
\hline Büyücü & $\begin{array}{l}\text { Karakter } \\
8 \text { Ürün }\end{array}$ & 3 Ürün & 1 Ürün \\
\hline Kral & & & 3 \\
\hline Hiçbiri & & & \\
\hline
\end{tabular}

Tabloya Iliş̧kin Verilerin Analizi: Inşaat sektöründe 34 kez karakterde, 26 kez ise üründe arketipe rastlanmıştır. Sektörde arketiplerin en fazla saptandığı reklam toplam 32 kez ile EnerjiSa olmuştur. Karakterlerde arketiplerin en fazla kullanıldığının saptandığı reklam 24 kez ile EnerjiSa, üründe ise 10 kez ile İpragaz reklamı olmuştur. Sektörde en fazla kullanılan arketip 1 kez karakterde 14 kez ise üründe olmak üzere büyücü olmuştur. Karakterde kullanıldığı en çok saptanan arketip 10 defayla sıradan adam, üründe ise 14 defayla büyücü olmuştur.

Sektörve Kullanılan Arketiplere YönelikAnaliz: Enerji ve akaryakıt sektöründe faaliyet gösteren markaların kendilerini mümkün olmayan şeyleri mümkün kılan bir marka olarak konumlandırmaya çalıştıkları söylenebilir. Karakterde en çok saptanan arketipin sıradan adam olması da bu iddiayı desteklemektedir. Markaların sıradan adamların hayatlarını değiştirdiğini iddia ettiği yönünde yorum yapılabilir. 
Tablo 11. Mobilya Sektörüne Ait Veriler

\begin{tabular}{|l|l|l|l|}
\hline & Bellona & İstikbal & Mondi \\
\hline Masum & & & 1 Karakter \\
\hline $\begin{array}{l}\text { Sıradan } \\
\text { Adam }\end{array}$ & 3 Karakter & & $\begin{array}{l}2 \text { Karakter } \\
\text { 2 Ürün }\end{array}$ \\
\hline Kahraman & & & \\
\hline Yardımsever & 1 Ürün & & \\
\hline Kaşif & & & \\
\hline Asi & 1 Karakter & & \\
\hline Aşık & 2 Karakter & & 3 Karakter \\
\hline Yaratıcı & & & 5 Ürün \\
\hline Soytarı & & & \\
\hline Bilge & 3 Ürün & & \\
\hline Büyücü & 1 Ürün & & 1 Karakter \\
\hline Kral & & & \\
\hline Hiçbiri & 4 & 10 & \\
\hline
\end{tabular}

Tabloya Ilişkin Verilerin Analizi: Mobilya sektöründe kodlayıcılar 13 kez karakterde 13 kez de üründe arketipe rastlarken, 14 kez ise ilgili reklamlarda hiçbir arketip olmadığını belirtmişlerdir. Söz konusu sektörde arketiplerin en fazla saptandığı reklam toplam 15 kez ile Mondi olmuştur. Karakterlerde ve üründe arketiplerin en fazla kullanıldığının saptandığı reklam sırasıyla 7 ve 8 defa ile Mondi olmuştur. Sektörde en fazla kullanılan arketip 5 kez karakterde, 2 kez de üründe olmak üzere sıradan adam olmuştur. Karakterde kullanıldığı en çok saptanan arketip 5 kez ile sıradan adam ve aşık, üründe ise 5 kez ile yaratıcı olmuştur.

Sektör ve Kullanılan Arketiplere Yönelik Analiz: Bu bağlamda mobilya sektörünün ürün tanıtımına odaklanan yapısı yüzünden arketiplere fazlaca başvurmadığı söylenebilir. Zaten televizyonda fazla reklamı bulunmayan sektörün genel olarak kısa reklamlar kullandığı, bu yüzden zaten arketip kullanmaya yatkın reklamlar oluşturmadığı görülebilir. Dolayısıyla, oldukça fazla kodlayıcı tarafından reklamlarda hiçbir arketipin bulunmamasının sebebi bu şekilde yorumlanabilir.

\section{Araştırmanın Sonuçları}

Çalışma sonucunda özellikle 12 arketipin de Türk televizyonlarında kullanılıyor olduğunun ortaya konulmuş olması önemlidir. Buna ek olarak reklamlarda sektörel anlamda bazı arketiplerin yoğun olarak görülmesi hangi sektörde hangi arketiplerin kullanıldığının ortaya konması bakımında önemli veriler sağlamaktadır. Reklamın hedef kitleyi etkilemek adına tek yönlü bir 
iletişim olduğunu ve söz konusu iletişim faaliyetinden önce araştırmanın önemli bir görevi olduğunu düşündüğümüzde, karşımıza çıkan tablonun oldukça anlamlı olduğunu söylemek mümkündür; çalışmaya konu olan her sektörde belirli bir arketipe yönelik yığılım gerçekleşmiştir. Dolayısıyla bu durum markaların ne tarz bir ürün satarken hangi tür arketipi kullanacakları konusunda bilinçli olduklarının bir göstergesi olarak yorumlanabilir.

Çalışma kapsamında 10 kodlayııının karakterler ve ürünlerde toplam 751 kez arketip bulması Türk reklamlarının ne ölçüde yoğunlukta arketipsel imgeler içerdiğini ortaya koymaktadır. Özellikle EnerjiSa reklamında 10 kodlayıcının 32 kez arketip bulması bir reklamın bile kaç farklı arketipsel imge içerebileceği yönünde önemli bir veri sağlamaktadır. Söz konusu reklamda 12 arketipin 7'si kodlayıcılar tarafından tespit edilirken yalnızca 5 arketip türünün olmadığı ortaya koyulmuştur. Durum her reklam için benzerlik göstermese de birden fazla arketipin kullanıldığı reklam sayısının oldukça fazla olduğu gözlemlenmiştir.

Özellikle konuya sektörel bağlamda baktığımızda bazı arketiplerin bazı sektörlerde hiç kullanılmadığını görmekteyiz. Örnek olarak asi arketipinin inşaat sektöründe kullanılmamış olması aklımıza inşaat firmalarının güvenli ve konforlu bir hayat sunma vaatlerini aklımıza getirmektedir. Asi arketipi ise mevcut düzeni yıkma amacını içinde barındırmaktadır. Dolayısıyla markaların özellikle kendi ana vaatlerini destelemeyen arketiplerden uzak durduğu; temel vaatlerini destekleyen arketipleri ise kullanmaktan kaçınmadıkları söylenebilir.

Araştırma sonucunda ulaşlan diğer bir veri olan arketiplerin karakterde mi yoksa üründe mi kullanıldı̆ıı ise yine benzer şekilde sektörel anlamda önemli bilgiler sağlamaktadır. Araştırmaya konu olan sektörler genel olarak arketipleri reklamların içine karakter ve ürüne yönelik olarak dengeli yerleştirirken, inşaat sektörü dikkat çekici bir şekilde arketipleri ürüne yerleştirme yoluna gitmiştir. Gıda sektörü ise tam tersi bir görünüm sergileyecek arketipleri karakterlere yerleştirme yoluna gitmiştir. Bunun sebebi inşaat sektöründe ürünün sunduğu vaadin, gıda sektöründe ise ürünü satın aldıktan sonra karakterlerin yaşadığı değişimin önemli olması şeklinde yorumlanabilir. Daha açık bir ifadeyle, gayrimenkul satın almak için belirli bir ekonomik düzeyde olmak gerekmektedir. Bu düzeydeki insanlar hayatlarını kolayca değiştirebilme imkanına sahiptir. Öte yandan gıda sektörü ortalama ekonomik düzeydeki insanlara seslenmekte ve söz konusu topluluk küçük uğraşlarla monoton hayat üzerinde değişiklik yapma vaadine daha açık bir görünüm sergilemektedir.

Yine aynı şekilde araştırmaya konu olan 8 sektörde en fazla kullanılan arketipe baktığımızda 6 farklı arketipin baskın olarak kullanıldığını görebiliriz. Yalnızca yardımsever ve büyücü arketipleri iki farklı sektörde en baskın arketip olmuştur. Bu bağlamda özellikle sektörel değerlendirme yaptığımızda hizmet sektöründe değerlendirebileceğimiz markalar, yani, finans ve teknoloji sektörleri kendilerini yardımsever olarak konumlandırırken; nispeten lüks tüketim içine dahil 
edebileceğimiz kozmetik ve temizlik ile enerji ve akaryakıt sektörleri kendilerini büyücü olarak konumlandırmıştır. Gıda sektörü gülmeceden yaralanırken; lüks tüketimin diğer bir boyutu olan otomotiv sektöründeki markalar kendini öğüt veren bir bilge olarak konumlandırmıştır. İnşaat sektörü yeni bir hayat vaadi ile bu yeni hayatı kurabilecek bir yaratıcı olduğunu vurgularken, mobilya sektörü sıradan adamların bile sahip olabileceği mutluluk hayali sunmuştur.

Araştırma sonuçlarını arketipsel bağlamda değerlendirdiğimizde en çok kullanılan ilk üç arketipin sırasıyla yardımsever, sıradan adam ve soytarı olması da kültürel anlamda önemli verilere işaret etmektedir. Reklamların yerel bir bakış açısıyla oluşturulması gerekliliği zaten birçok araştırma kapsamında ortaya konulmuş bir gerekliliktir. Dolayısıyla, Türk televizyonlarında gösterilen reklamların bu gerekliliğe uyduğu söylenebilir. Türkiye'de yaşayanların kendilerini genelde yardımsever, sıradan ve eğlenceli olarak tanımladığını, benzer şekilde bu bahsettiğimiz özelliklere sahip dizi karakterlerinin izleyicide sempati yarattığını düşündügü̈müzde reklamlarda da neden adı geçen üç arketipin en baskın olarak kullanıldığı daha anlamlı bir boyuta ulaşmaktadır.

Özellikle araştırma kapsamında Türkiye'de en fazla reyting alan kanallarda en çok tekrar eden reklamların, yani tüm televizyon izleyicilerinin en fazla izlediği reklamların ele alındığı düşünüldügünde araştırmanın sonuçlarının genel olarak Türkiye'deki tüm televizyon reklamlarına yönelik bir genellemeye temel oluşturabileceği söylenebilir. Ancak tüm reklamların -özellikle kısa ve basit yapıdaki reklamların- arketip içermediği göz önüne alındığında özellikle karmaşık senaryo ağına sahip reklamların kaçınılmaz olarak arketiplerden yararlandığı iddia edilebilir.

Kısaca, analizin verileri arketip ve reklam ilişkisine yönelik genel bir çerçeve çizerken, kültürel bağlamda arketiplerin farklılaşabileceği düşünüldügünde, araştırmanın sonuçlarının genel niteliği taşımadığını, yalnızca Türkiye ile sınırlı olduğunu söylemek mümkündür. Ancak, benzer şekilde, farklı bir kültürde benzer bir çalışma yapılması durumunda çalışmanın sonuçlarının arketipsel bağlamda benzer olabileceğini öngörsek de sektörel ve genel anlamda en çok kullanılan arketiplerin farklılık göstereceği söylenebilir.

Araştırma kapsamında hipotezlerin tümü doğrulanmıştır. Ortaya konulan veriler ve hipotezlerle ilişkileri aşağıdaki gibidir:

H1: Beklendiği gibi arketipsel imgelerin reklamda baskın olarak kullanıldığı ortaya çıkmıştır. Araştırma kapsamında 10 kodlayıcının karakterler ve ürünlerde toplam 751 kez arketip bulması bunun kanıtıdır.

H2: Yine benzer olarak öngörüldüğ̈̈ gibi Türk reklamlarında arketip kullanımı ürün -368 kez saptanmıştır- ve karakter -387 kez saptanmıştır- arasında denge göstermiştir. 
H3: Araştırma öncesinde beklendiği gibi yardımsever arketipi en çok kullanılan arketip olmuştur. Söz konusu arketip 18 kez karakterde 113 kez ise üründe olmak üzere toplam $131 \mathrm{kez} \mathrm{saptanmıştır.}$

H4: Aynı şekilde öngörüldüğü gibi genel anlamda, yani tüm sektörler göz önüne alındığında beklendiği gibi hizmet sektöründe yardımsever arketipi yoğun olarak görülürken her sektörde belirli arketiplerin baskınlığı gözlenmiştir.

\section{Tartışma}

Arketipler genel anlamda pazarlamada, özel anlamda ise reklamlarda sıklıkla başvurulan, ikna etmeye yardımcı araçlardır. Insanların bilindik sembollerin etkisine daha açık olduğu ve söz konusu sembollerin iknayı kolaylaştırdığı zaten geçmiş pek çok araştırmada kanıtlanmıştır bir olgudur (Olson, 1975; Kaftandjiev, 2016). Bu yüzden de bu araştırmanın sonucu, bahsedilen, zamanı geçmiş sorunun bilindik cevabını tekrar aramak yerine ülkemizde hangi arketipin hangi sektöre ait reklamda daha baskın olduğunu ve arketiplerin karakterde mi yoksa üründe mi daha çok kullanıldığının cevabını vermeyi amaçlamıştır.

Durum Türk televizyonları açısından değerlendirildiğinde, her sektörel reklamın kendine en uygun düşecek arketipleri hali hazırda kullandığını söylenebilir. Hedef kitlenin istekleri doğrultusunda saptanmış söz konusu arketipler ürünün arketipsel özellikler ile özdeşleşmesini sağlarken izleyici-tüketicinin zihnindeki kalıplara hitap ederek ikna yönünde olumlu bir etki yaratmaktadır.

Reklamlar artık ürün satmanın yanında hayal satmak ve imaj oluşturma ile ilintili olduğundan reklamlarda ürünlerin özelliklerinden çok arketiplerin öne çıkarılması sürpriz bir sonuç değildir. Artık günümüzde aynı sektördeki ürünlerin nerdeyse hepsi benzer özellikler taşımaktadır. Ürünleri farklılaştıran ise sunulan vaat ve hayaldir. Günümüzde reklamlarda arketiplerin kullanılmasının sebebi de tam olarak budur. Bir edebiyat eserinde her zaman kahraman, anti kahraman, bilge gibi arketiplerin metin içinde yer aldığı düşünüldüğünde, konu veya hayal yaratmanın kaçınılmaz olarak arketiplerle iç içe olduğu görülebilir. Reklam da tüketiciye bir gelecek planı -gelecek planından kası ürünü satın aldıktan sonra tüketicinin ulaşacağı yeni durum- sunduğundan kaçınılmaz olarak arketiplerden yararlanmaktadır.

Reklam bir yandan baskın grupların intiyaçlarına yönelirken, bir yandan da azınlığın intiyacını baskın konuma getirmektedir. Bir rıza üretimi olarak tanımlayabileceğimiz reklamlar önemini insanları etkileyebilme gücünden alırken, markalar açısından reklam, ürünlerini geniş kitlelere ulaştırabilme imkanını ifade etmekte; tüketiciler için ise yüzlerce alternatif arasından en doğrusunu seçme özgürlüğü ile bütünleşmektedir.

Reklamlar ikna bağlamında değerlendirildiğinde, reklamların oldukça güçlü bir ikna aracı olarak düşünüldüğü söylenebilir. Kurumların sıklıkla reklam 
vermesi ve kurumların reklam harcamalarına önemli bir pay ayırması bunun bir göstergesi olarak değerlendirilebilir. Geçmiş uygulamalar göz önüne alınarak, reklamın arketipsel öğelere dayandırımasının oldukça fazla olduğu (MasoFleischman, 1997; Groeppel-Klein vd. 2006; Yakın vd., 2014; Ay ve Yakın, 2017) değerlendirildiğinde, reklamcıların da yeni arayışlara yönelmek yerine bilindik temalar üzerinden hareket ettiği söylenebilir.

Tüm bunlar göz önüne alındığında, araştırma, daha kapsamlı araştırmalar için temel oluşturmayı hedeflerken reklam analizine yönelik farkı bir niceliksel yaklaşım sunmaktadır. Bu bağlamda içerisinde bazı eksiklikler bulundursa da bir yenilik oluşturmayı amaçlamaktadır. Geçmiş araştırmalar arketipleri marka kişiliği üzerinden değerlendirmiş (Yakın vd., 2014; Bechter vd., 2016), arketiplerin propaganda aracı olarak nasıl kullanıldığına değinmiş (Kaftandjiev, 2016), tek bir sektöre yönelik arketip ve reklam ilişkisine yönelik değerlendirme sunmuş (Ay ve Yakın, 2017), analizleri belirli kampanyalarla sınırlamış (Maso-Fleischman, 1997) ve izleyicinin reklam, marka ve film hakkında bilinçli değerlendirmelerini etkileyip etkilemediğine (Groeppel-Klein vd., 2006) odaklanmıştır. Bu çalışma ise en fazla izlenen Türk reklamlarına yönelerek hem Türkiye için reklamlarda arketip kullanımı aşamasında genel bir tablo çizmiş hem de sektörel karşılaştırmalı analiz ile sektörler arasındaki arketipsel imgelerin farklılaşma niteliğini ortaya koyarak arketiplerin sektörel anlamda bilinçli oluşturulup oluşturulmadığına yönelik bir çözümleme sunmuştur. Buna ek olarak, araştırma, arketiplerin reklamda karakterlere mi yoksa ürüne mi yerleştirildiği konusuna değinmesi açısından da önem taşımaktadır. Bu noktadan hareketle, gelecek çalışmaların odaklanması gereken konu ise bilinçdışı etkilerin, özellikle arketipsel öğelerin karar alma ve davranışa etkilerinin neler olduğu, bunun bir anlık etki mi yoksa sürekli veya gecikmeli bir etki mi olduğu, diğer bir ifadeyle mesaja maruz kalınan zaman diliminden sonraki aşamalarda tutumları içsel olarak etkileyip etkilemediği olmalıdır. Diğer bir yönelinebilecek noktanın ise, hangi arketipin hangi sektörde en fazla kullanıldığını tespit etmekten öteye giderek, hangi sektör için hangi arketipi kullanmanın en etkili olduğu yönünde bir araştırma olabileceği söylenebilir.

Sonuçlara bakıldığında arketipsel imge kullanım eğiliminin son derece yüksek olduğu ve örneklemi oluşturan reklamların büyük bölümünün içinde birden fazla arketipsel imge bulundurduğu ortaya çıkmıştır. Kısaca araştırma sonuçları ışığında denilebilir ki; arketipsel imgeler ile reklam olgusu iç içe geçmiş bir görünüm sergilemektedir. Ancak şu da unutulmamalıdır ki bu araştırmanın amacı reklamlarda ikna için arketip kullanılmasını yüceltmek veya yermek değildir. Araştırma yalnızca mevcut olanın niteliğini ortaya koymaya çalışmaktadır. Dolayısıyla, araştırma kapsamında reklamın bir ikna faaliyeti olup olmaması gereğinin, reklamda arketip kullanılıp kullanılmaması gereğinin, ya da daha geniş bir ifadeyle reklamda ikna amacı ile arketip kullanılıp kullanılmamasının tartışılmadığı söylenebilir. Araştırma yalnızca mevcut olarak reklamların ikna etme aracı olduğu gerçeğinden hareketle, araştırma sonuçlarının da kanıtladığı gibi, reklamlarda bu denli fazla arketipsel imge yer almasının ikna ile ilişkili düşünülebileceği iddiasını 
ortaya koymaktadır. Reklam bir ikna etme aracı ise reklamcıların da iknayı en üst düzeyde arttıracak öğelere başvuracağı söylenebilir. Dolayısıyla reklamlardaki arketip oranının bu konu ile ilgili ipuçları sağladığı, reklam yaratıcılarının bilinçli olarak arketip kullanma yoluna başvurduğu iddia edilebilir.

\section{Kaynakça}

Adi, A., Crişan, C. ve Dincă, R. C. (2015). Stories, Heroes and Commercials: Spreading The Message Across with a New Type of Responsibility. Management Dynamics in the Knowledge Economy, 3(4), 749-764.

Anık, C. (2000). Siyasal Ikna. Ankara: Vadi Yayınları.

Ay, C., ve Yakın, V. (2017). Reklamlarla Marka Kişiliği Geliştirmek: Arketipler Tüketicileri Yakalayabiliyor Mu?. İstanbul Üniversitesi İşletme Fakültesi Dergisi, 46(2), 161-178.

Ayanwale, A. B., Alimi, T., ve Ayanbimipe, M. A. (2005). The Influence of Advertising on Consumer Brand Preference. Journal of social sciences, 10(1), 9-16.

Aylesworth, A. B., Goodstein, R. C., ve Kalra, A. (1999). Effect of archetypal embeds on feelings: An indirect route to affecting attitudes?. Journal of Advertising, 28(3), 73-81.

Batır, F. ve Gürbüz, S. (2016). Türkiye'nin toplumsal kültür eğilimleri: Globe araştırmasından sonra ne değişti? 24. Ulusal Yönetim ve Organizasyon Kongresi Bildiriler Kitabı, 427-438, 28-31 Mayıs 2016, İstanbul.

Bechter, C., Farinelli, G., Daniel, R. D., ve Frey, M. (2016). Advertising between archetype and brand personality. Administrative Sciences, 6(2), 5.

Berger, J. (2011). Görme Biçimleri. İstanbul: Metis Yayınları.

Bermeitinger, C., Goelz, R., Johr, N., Neumann, M., Ecker, U. K., ve Doerr, R. (2009). The hidden persuaders break into the tired brain. Journal of Experimental Social Psychology, 45(2), 320-326.

Campbell, J. (2008). The Hero with a Thousand Faces (Vol. 17). New World Library.

Darıcı, S. (2013). Bilinçaltı Reklamcılık ve Iletişim Teknikleri. İstanbul: İstanbul Gelişim Üniversitesi Yayınları.

Demir, Y., Eroğlu, A. H. ve Bayraktar, S. (2013). Bankaların Kurumsal Reklam Uygulamalarının Kurum Imajına Etkisi. Trakya Üniversitesi Iiktisadi ve Idari Bilimler Fakültesi E-Dergi, 2(1), 1-25.

Demirkol, N. (2008). Ingiliz Roman geleneğinde Çocuk Edebiyatının Gelişimi: Arketipçi Eleştiri Kuramına Göre Alice Harikalar Diyarında, Define Adası, Orman 
Kitabı Eserlerinin Incelenmesi. Yayınlanmamış Yüksek Lisans Tezi, Ankara Üniversitesi.

Demirtaş Madran, A. (2012). Tutum, Tutum Değişimi ve ikna. Ankara: Nobel Yayınları.

Du Toit, D. ve Coetzee, M. (2012). Archetypal Values of Science and Engineering Staff in Relation to Their Career Orientations. SA Journal of Industrial Psychology, 38(1), 1-14.

Groeppel-Klein, A., Domke, A., ve Bartmann, B. (2006). Pretty Woman Or Erin Brockovich? Unconscious and Conscious Reactions to Commercials and Movies Shaped By Fairy Tale Archetpyes-Results From Two Experimental Studies. Advances in Consumer Research, 33, 163-174.

Güleç, B. (2006). Reklamın Turistlerin Satın Alma Davranışları Bakımından Incelenmesi. Balıkesir Üniversitesi Sosyal Bilimler Enstitüsü Dergisi, 9(15), 127158.

Gümüş, S. (2009). "Macbeth" Filminin Roman Polanski Uyarlamasının Rüya ve Sanrı Sahnelerinin Jungçu Psikanalitik Simgelerinin Göstergebilimsel Çözümlemesi. Yayınlanmamış Yüksek Lisans Tezi, İstanbul Üniversitesi.

Gürbüz, S., ve Şahin, F. (2016). Sosyal Bilimlerde Araştırma Yöntemleri. Ankara: Seçkin Yayıncılık.

İleri, D. (2012). 1980 Sonrası Sanat ve Reklam Üzerine Temel Yaklaşımlar. Yayınlanmamış Yüksek Lisans Tezi, Gazi Üniversitesi.

Jung, C. G. (1969). Collected Works of CG Jung, (Volume 9): Archetypes and the Collective Unconscious. London: Routledge.

Jung, C. G. (1976). The Symbolic Life: Miscellaneous Writings. Princeton: Princeton University Press.

Jung, C. G. (2013). Dört Arketip. İstanbul: Metis Yayınları

Kaftandjiev, C. (2016). Archetypes and Propaganda. Propaganda in the World and Local Conflicts, (2), 87-100.

Karabulut, M. (2015). İmgenin Psikanalitik Boyutu. Adıyaman Üniversitesi Bilim, Kültür ve Sanat Sempozyumu-II. Adıyaman: Adıyaman Üniversitesi.

Karadoğan Doruk, E. (2015). İknanın Sosyal Psikolojisi. İstanbul: Derin Yayınları.

Karremans, J. C., Stroebe, W., ve Claus, J. (2006). Beyond Vicary's fantasies: The impact of subliminal priming and brand choice. Journal of Experimental Social Psychology, 42(6), 792-798.

Key, W. B. (1993). The Age of Manipulation The Con in Confidance The Sin in Sincere. Maryland: Medison Books. Orginally Published New York.

Kırdar, Y. (2012). Mysticism in subliminal advertising. JAMMO, 4(15), 222-239. 
Kociatkiewicz, J. ve Kostera, M. (2012). The Good Manager: An Archetypical Quest for Morally Sustainable Leadership. Organization Studies, 33(7), 861-878.

Mark, M. ve Pearson, C. S. (2001). The Hero and the Outlaw: Building Extraordinary Brands Through the Power of Archetypes. McGraw-Hill Education: NewYork.

Maso-Fleischman, R. (1997). Archetypal Research for Advertising: A SpanishLanguage Example. Journal of Advertising Research, 37(5), 81-85.

Mcluhan, M. (2001). The Medium is the Message. Gingko Press.

McPeek, R. W. (2008). The Pearson-Marr Archetype Indicator and Psychological Type. Journal of Psychological Type, 68(7), 52-66.

Munteanu, A., Costea, I., Palos, R. ve Jinaru A. (2010). Entering in the Essences Of Personality Studies Over Archetypes. Procedia Social and Behavioral Sciences, 5, 2272-2276.

Neuman, W. L. (2014). Toplumsal Araştırma Yöntemleri Nitel ve Nicel Yaklaşımlar I. Ankara: Yayın Odası.

Okur, A., Göçen, G. ve Süğümlü, Ü. (2013). İkna Edici Yazma ve Karşılaştırmalı Bir Araştırma (Avustralya Ana Dili Öğretimi Ders Materyalleri ve Türkiye Örneği). Mustafa Kemal Üniversitesi Sosyal Bilimler Enstitüsü Dergisi, 10(21), 167-197.

Olson, M. C. (1975, march 20-22). Subliminal Messages in Advertising. English Education Conference. 13th, Colorado Springs: Colorado.

Sağlam Arı, G., Armutlu, C., Güneri Tosunoğlu, N., ve Yücel Toy, B. (2009) Pozitivist ve Postpozitivist Paradigmalar Çerçevesinde Metodoloji Tartışmalarının Yönetim ve Pazarlama Alanlarına Yansımaları. Hacettepe Üniversitesi İtisadi ve idari Bilimler Fakültesi Dergisi, 27(1), 113-141.

Seçim, M. Ö. (2013). Toplumsal Değişimlerin Siyasal Reklama Yansımaları: 20002010 Türkiye Örneği. Yayınlanmamış Yüksek Lisans Tezi, Ege Üniversitesi.

Siraj, S. ve Kumari, S. (2011). Archetyping the Brand: Strategy to Connect. The IUP Journal of Brand Management, 8(3), 47-59.

Solmaz, I. (2014). Nöropazarlama Faaliyetlerinde Bilinçaltı Reklamclık ve Tüketici Algısı Üzerindeki Etkisi. Yayınlanmamış Yüksek Lisans Tezi, Gediz Üniversitesi.

Swasy, J. L. ve Munch, J. M. (1985). Examining the Target of Receiver Elaborations: Rhetorical Question Effects on Source Processing and Persuasion. Journal of Consumer Research, 11(4), 877-886.

Taheri, M. ve Jalaly R. (2013). The Archetype of the Hero's Journey in Odyssey. International Journal of Language Learning and Applied Linguistics World (IJLLALW) 4(2), 246-260.

Tosyalı, T. (2014). Reklam: Göstergebilimsel Çözümleme ve Markalaşma. Yayınlanmamış Yüksek Lisans Tezi, Marmara Üniversitesi. 
Villate, V. M. (2012). Qualitative Research as a Hero's Journey: Six Archetypes to Draw on. The Qualitative Report, 17(38), 1-9.

Wilson, E. J. ve Sherrell, D. L. (1993). Source Effects in Communication and Persuasion Research: A Meta-Analysis of Effect Size. Journal of the Academy of Marketing Science, 21(2), 101-112.

Woodside, A. G. ve Megehee, C. M. (2009). Travel Storytelling Theory and Practice. Anatolia, 20(1): 86-99.

Woodside, A. G., Megehee, C. M. ve Sood, S. (2012). Conversations with (in) the Collective Unconscious by Consumers, Brands, and Relevant Others. Journal of Business Research, 65(5), 594-602.

Yakın, V., Canan, A. Y., ve Yakın, M. (2014). Reklamlarda Kullanılan Marka Kişilik Arketiplerinin Göstergebilimsel Analizi. Yönetim ve Ekonomi: Celal Bayar Üniversitesi İktisadi ve Idari Bilimler Fakültesi Dergisi, 21(1), 345-355.

Yücel, H. (2017). Kurumsal Reklamcılık Algılamasına Yönelik Bir Araştırma: Ziraat Bankası Örneği. Erciyes Illetişim Dergisi, 5(2), 44-59.

Zambo, D. (2007). Using Picture Books to Provide Archetypes to Young Boys: Extending the Ideas of William Brozo. The Reading Teacher, 61(2), 124-131. 
